Canadian

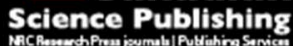

Applied Physiology, Nutrition, and Metabolism Physiologie appliquée, nutrition et métabolisme

\title{
Systematic review of the relationships between sleep duration and health indicators in school-aged children and youth
}

\begin{tabular}{|c|c|}
\hline Journal: & Applied Physiology, Nutrition, and Metabolism \\
\hline Manuscript ID & apnm-2015-0627.R1 \\
\hline Manuscript Type: & Review \\
\hline Date Submitted by the Author: & 04-Jan-2016 \\
\hline Complete List of Authors: & $\begin{array}{l}\text { Chaput, Jean-Philippe; CHEO Research Institute, Healthy Active Living and } \\
\text { Obesity Research Group } \\
\text { Gray, Casey; Children's Hospital of Eastern Ontario Research Institute, } \\
\text { Healthy Active Living and Obesity Research } \\
\text { Poitras, Veronica; Childrens Hospital of Eastern Ontario Research Institute, } \\
\text { Healthy Active Living and Obesity Research Group } \\
\text { Carson, Valerie; University of Alberta, Faculty of Physical Education and } \\
\text { Recreation } \\
\text { Gruber, Reut; Douglas Mental Health University Institute } \\
\text { Olds, Timothy; University of South Australia } \\
\text { Weiss, Shelly; University of Toronto } \\
\text { Connor Gorber, Sarah; Canadian Institutes of Health Research } \\
\text { Kho, Michelle; McMaster University } \\
\text { Sampson, Margaret; Childrens Hospital of Eastern Ontario Research } \\
\text { Institute } \\
\text { Belanger, Kevin; Children's Hospital of Eastern Ontario Research Institute } \\
\text { Eryuzlu, Sheniz; Children's Hospital of Eastern Ontario Research Institute } \\
\text { Callender, Laura; Children's Hospital of Eastern Ontario Research Institute } \\
\text { Tremblay, Mark; Childrens Hospital of Eastern Ontario Research Institute, }\end{array}$ \\
\hline Keyword: & Sleep duration, Mental health, Physical health, Children, Population health \\
\hline
\end{tabular}

\section{SCHOLARONE}

Manuscripts 


\section{Systematic review of the relationships between sleep duration and health indicators in school-aged children and youth}

Jean-Philippe Chaput, Casey E. Gray, Veronica J. Poitras, Valerie Carson, Reut Gruber, Timothy Olds, Shelly K. Weiss, Sarah Connor Gorber, Michelle E. Kho, Margaret Sampson, Kevin Belanger, Sheniz Eryuzlu, Laura Callender, and Mark S. Tremblay

\section{Corresponding Author:}

Jean-Philippe Chaput, $\mathrm{PhD}$

Healthy Active Living and Obesity Research Group

Children's Hospital of Eastern Ontario Research Institute

401 Smyth Road, Ottawa, ON, Canada, K1H 8L1

Phone: +1 6137377600 ext. 3683; Fax: +1 613738 4800; Email: jpchaput@cheo.on.ca

\section{J.P. Chaput, C.E. Gray, V.J. Poitras, M. Sampson, K. Belanger, S. Eryuzlu, L. Callender and M.S. Tremblay. Healthy Active Living and Obesity Research Group, Children's Hospital} of Eastern Ontario Research Institute, Ottawa, ON, Canada.

V. Carson. Faculty of Physical Education and Recreation, University of Alberta, Edmonton, AB, Canada.

R. Gruber. Attention, Behavior, and Sleep Laboratory, Douglas Mental Health University Institute, Verdun, QC, Canada.

T. Olds. Alliance for Research in Exercise, Nutrition and Activity (ARENA), Sansom Institute of Health Research, University of South Australia, Adelaide, Australia.

S.K. Weiss. Division of Neurology, The Hospital for Sick Children, University of Toronto, Toronto, ON, Canada.

S. Connor Gorber. Office of the Task Force on Preventive Health Care, Public Health Agency of Canada, Ottawa, ON, Canada (at the time of the study). Current affiliation and address:

Canadian Institutes of Health Research, Ottawa, ON, Canada.

M.E. Kho. School of Rehabilitation Science, McMaster University, Hamilton, ON, Canada.

Email contact:

J.P. Chaput (jpchaput@,cheo.on.ca); C.E. Gray (casgray@cheo.on.ca); V.J. Poitras (vepoitras@,cheo.on.ca); V. Carson (vlcarson@ualberta.ca); R. Gruber (reut.gruber@douglas.mcgill.ca); T. Olds (Timothy.Olds@unisa.edu.au); S.K. Weiss (shelly.weiss@sickkids.ca); S. Connor Gorber (Sarah.ConnorGorber@cihr-irsc.gc.ca); M.E. Kho (khome@mcmaster.ca); M. Sampson (msampson@cheo.on.ca); K. Belanger

(kbelanger@cheo.on.ca); S. Eryuzlu (seryuzlu@cheo.on.ca); L. Callender (Laura.callender@hotmail.com); M.S. Tremblay (mtremblay@cheo.on.ca)

PROSPERO 2015: CRD42015015492 Available from:

http://www.crd.york.ac.uk/PROSPERO/display_record.asp?ID=CRD42015015492 


\begin{abstract}
The objective of this systematic review was to examine the relationships between objectively and subjectively measured sleep duration and various health indicators in children and youth age 517 years. Online databases were searched in January 2015 with no date or study design limits. Included studies were peer-reviewed and met the a priori determined population (apparently healthy children and youth age 5-17 years), intervention/exposure/comparator (various sleep durations), and outcome (adiposity, emotional regulation, cognition/academic achievement, quality of life/well-being, harms/injuries, and cardiometabolic biomarkers) criteria. Due to high levels of heterogeneity across studies, narrative syntheses were employed. A total of 141 articles (110 unique samples), including 592,215 unique participants from 40 different countries, met inclusion criteria. Overall, longer sleep duration was associated with lower adiposity indicators, better emotional regulation, better academic achievement, and better quality of life/well-being. The evidence was mixed and/or limited for the association between sleep duration and cognition, harms/injuries, and cardiometabolic biomarkers. The quality of evidence ranged from very low to high across study designs and health indicators. In conclusion, we confirmed previous investigations showing that shorter sleep duration is associated with adverse physical and mental health outcomes. However, the available evidence relies heavily on cross-sectional studies using self-reported sleep. In order to better inform contemporary sleep recommendations, there is a need for sleep restriction/extension interventions that examine the changes in different outcome measures against various amounts of objectively-measured sleep to have a better sense of doseresponse relationships.
\end{abstract}


Key words: sleep duration, adiposity, body weight, emotional regulation, mental health, cognition, academic achievement, quality of life, well-being, injuries 


\section{Introduction}

Sleep is an essential component of healthy development and is required for physical and mental health. However, sleep deprivation has become common in contemporary societies with 24/7 availability of commodities (Akerstedt and Nilsson 2003; Ohayon 2012). School-aged children and youth generally sleep less now compared with decades ago (Keyes et al. 2015; Matricciani et al. 2012a), and factors responsible for this secular decline in sleep duration are generally ascribed to the modern way of living (e.g. artificial light, late-night screen time, caffeine use, and no bedtime rules in the household) (Gruber et al. 2014). Chronic sleep loss and associated sleepiness and daytime impairments pose serious threats to the academic success, health, and safety of children and youth and are important public health issues (Owens 2014). Understanding the implications of insufficient sleep during childhood is critical in setting public policies and developing promising strategies aimed at mitigating the adverse effects of sleep deprivation.

A large number of studies have confirmed the importance of healthy sleep for various outcomes; however, a systematic review of studies that examined the influence of sleep duration on key health indicators in children and youth, a critical period for growth and development, is lacking. A comprehensive assessment of the relationships between sleep duration and various health indicators in children and youth is important to determine if the current sleep duration recommendations are evidence-informed. The National Sleep Foundation recommends sleeping between 9-11 hours/night for school-aged children (ages 6-13 years) and 8-10 hours/night for adolescents (ages 14-17 years) in order to maximize overall health and well-being (Hirshkowitz et al. 2015). Although the ideal amount of sleep per night varies from one person to another, sleep duration recommendations play an important role in informing public policies, guidelines, 
interventions, and parents and children/youth of healthy sleep behaviours (Matricciani et al. 2013; Matricciani et al. 2012b).

The objective of this systematic review was to examine the relationships between objectively and subjectively measured sleep duration and a broad range of health indicators in children and youth age 5-17 years. Findings from this review will help inform and possibly confirm current sleep duration recommendations for children and youth.

\section{Materials and Methods}

\section{Protocol and Registration}

This review was registered a priori with the International Prospective Register of Ongoing Systematic Reviews (PROSPERO; Registration no. CRD42015015492; Available from http://www.crd.york.ac.uk/PROSPERO/display_record.asp?ID=CRD42015015492), and was conducted following the PRISMA statement for reporting systematic reviews and meta-analyses (Moher et al. 2009).

\section{Eligibility Criteria}

The participants, interventions, comparisons, outcomes and study design (PICOS) framework (Schardt et al. 2007) was followed to identify key study concepts in the research question $a$ priori, and to facilitate the search process.

Population: Apparently healthy (including children with overweight and obesity) schoolaged children and youth, age 5-17 years (mean age 5-17.99 years) for at least one exposure measurement point. Clinical populations (e.g. patients with sleep apnea) were excluded. 
Intervention (exposure): Various sleep durations. Studies were included if they used objective (polysomnography, actigraphy, accelerometry) or subjective (self-report, proxy-report) measures.

Comparison: Various sleep durations. However, a comparator or control group was not required for inclusion.

Outcome: Six health indicators were chosen based on the literature, expert input and consensus, and recognition of the importance of including a broad range of health indicators. Five health indicators were identified as critical (primary) by expert agreement: (1) adiposity markers; (2) emotional regulation (e.g. stress, anxiety, depressive symptoms, mental health); (3) cognition/academic achievement; (4) quality of life/well-being; and (5) harms/injuries. One health indicator was identified as important (secondary) by expert agreement: cardiometabolic biomarkers (i.e. metabolic syndrome and cardiovascular disease risk factors).

Study design: All study designs were considered. For longitudinal studies, any follow-up length was allowed as long as the exposure was measured before follow-up at least once during the identified age range. Randomized controlled trials (RCTs) and other randomized interventions were required to have at least 30 participants in the intervention group. Observational studies were required to have a minimum sample size of 300 participants. For feasibility reasons related to the large number of studies examining adiposity, cross-sectional studies that examined adiposity and that used a self-report assessment of sleep, were required to have a minimum sample size of 1,000 participants.

\section{Information Sources and Search Strategy}

The electronic search strategy was created by a research librarian with expertise in systematic review searching and peer-reviewed by a second research librarian. See Supplement S1 for 
complete search strategies. The following databases were searched using the Ovid interface: MEDLINE (1946 to January 19, 2015), EMBASE (1980 to 2015 week 3), PsychINFO (1906 to 2015 week 3) and CINAHL (1961 to 2015 week 3).

\section{Study Selection}

Bibliographic records were extracted as text files from the OVID and EBSCO interfaces and imported into Reference Manager Software (Thompson Reuters, San Francisco, CA, USA) for removal of duplicate references. Titles and abstracts of potentially relevant articles were imported to DistillerSR (a secure, internet-based software; Evidence Partners, Ottawa, ON, Canada) where they were screened independently by two reviewers. Exclusion by both reviewers was required for a study to be excluded at level one; all other papers passed to level two, where two independent reviewers examined all full text articles. Consensus was required for articles to be included; discrepancies between reviewers were resolved by discussion between them or with a third reviewer, if needed. Reference lists of included articles and relevant reviews were also checked for additional relevant studies. Published peer-reviewed original manuscripts and inpress manuscripts were eligible for inclusion. Studies were included if they were published in English or could be translated using Google Translate.

\section{Data Collection Process}

Data extraction forms were created by the study coordinators, reviewed by study collaborators, and piloted by all reviewers. Extraction was completed in DistillerSR by one reviewer and exported to Excel to be checked for accuracy by a second reviewer. Reviewers were not blinded to the authors or journals when extracting data. Results were extracted from the most fully adjusted models for studies that reported findings from multiple models. 


\section{Data Items}

Important study features (e.g. publication year, study design, country, sample size, age and sex of participants, measure of sleep and health outcomes, results, and confounders) were extracted.

\section{Quality Assessment}

The risk of bias in primary research studies contributing to each health indicator was systematically evaluated using the methods described in the Cochrane Handbook (Higgins and Green 2011). The quality of evidence (i.e., the level of confidence that the estimates of effect are correct) for each health indicator by each type of study design was assessed using the Grading of Recommendations Assessment, Development and Evaluation (GRADE) framework (Guyatt et al. 2011). According to the GRADE framework, which categorizes evidence quality into four groups ("high", "moderate", "low” or "very low"), evidence quality ratings start at "high" for randomized studies and "low" for all other experimental and observational studies. The quality of evidence is downgraded if there are limitations across studies due to serious risk of bias, inconsistency of relative treatment effects, indirectness, imprecision or other factors. If there is no cause to downgrade, the quality of evidence can be upgraded if there is a large effect size, there is a dose-response gradient, or if all plausible confounders would decrease an apparent treatment effect. Overall quality of evidence for each study design within each health outcome was assessed by one reviewer and verified by the larger review team, including three systematic review methodology experts.

\section{Data Synthesis}

Meta-analyses were planned if results were found to be sufficiently homogenous in terms of statistical, clinical, and methodological characteristics. However, it was determined that a meta- 
analysis was not possible due to high levels of heterogeneity for the above characteristics across studies, and a narrative synthesis was performed for each health indicator.

\section{Results}

\section{Description of Studies}

As shown in Figure 1, a total of 5,815 records were identified through database searches and an additional 10 unique records were identified through reference list searches and through the review team and collaborators. After de-duplication, a total of 4,493 records remained. After titles and abstracts were screened, 318 full-text articles were obtained for further review and 141 articles met the inclusion criteria (110 unique samples). Reasons for excluding articles included: ineligible age $(n=35)$, no measure of sleep duration $(n=39)$, no measure of a health indicator of interest $(n=35)$, clinical population $(n=5)$, not original research (e.g. review; $n=2)$, sample size too small $(\mathrm{n}=51)$, non-English language article that could not be translated by Google Translate $(n=5)$, and unable to obtain the full text $(n=5)$. Some studies were excluded for multiple reasons.

Individual study characteristics are summarized in Supplementary Table S1 ( $n=186$, because some articles had more than one outcome measure). Data across studies involved 592,215 participants (from unique samples) and 40 different countries. Individual studies were randomized trials $(n=6)$, longitudinal studies $(n=33)$, cross-sectional studies $(n=145)$ or casecontrol studies $(\mathrm{n}=2)$. Sleep duration was measured objectively (polysomnography or actigraphy/accelerometry) in 29 studies. In the remaining 157 studies, sleep duration was measured subjectively via self-report or parent-report questionnaires. 


\section{Data Synthesis}

Adiposity

A total of 71 studies examined the association between sleep duration and adiposity indicators (Table 1 and Supplementary Table S1). One study used a randomized cross-over design, 12 studies used a longitudinal design, and 58 studies used a cross-sectional design. The randomized trial (Hart et al. 2013) showed that increased sleep duration resulted in lower weight after a week compared with decreased sleep (mean difference in weight of $0.24 \mathrm{~kg}, \mathrm{p}<0.001$, Cohen's $d=$ 0.93). There was a $2.4 \mathrm{~h}$ sleep duration difference between conditions ( $10.5 \mathrm{~h}$ vs. $8.1 \mathrm{~h}$ for the increased and decreased sleep, respectively, as reported with actigraphy). The quality of evidence was downgraded from high to moderate because only one randomized trial was published, so the risk of imprecision is high. Among the 12 longitudinal studies, 7 reported a significant association between short sleep duration and adiposity gain while 5 reported null findings. The quality of evidence was downgraded from low to very low due to a serious risk of bias. More specifically, only 2 studies (Hjorth et al. 2014a; Hjorth et al. 2014b) out of the 12 longitudinal studies used an objective measure of sleep duration. Finally, a total of 50 crosssectional studies (out of 58) reported a significant association between short sleep duration and excess adiposity. The other 8 studies reported null findings. Despite a serious risk of bias (i.e. most studies used a subjective assessment of sleep with no psychometric properties reported), the quality of evidence remained at low (as opposed to very low) because of the large effect observed and the evidence of a dose-response gradient between sleep duration and adiposity (upgrade). Indeed, longer sleep was consistently associated with lower adiposity indicators and with large effect sizes overall. 


\section{Emotional Regulation}

A total of 62 studies examined the association between sleep duration and emotional regulation, such as stress, anxiety, depressive symptoms and mental health (Table 2 and Supplementary Table S1). Four studies were randomized experiments, 11 studies used a longitudinal design, and 47 studies used a cross-sectional design. All four randomized trials (Vriend et al. 2013; Baum et al. 2014; Dagys et al. 2012; Tamura and Tanaka 2014) were consistent in showing better emotional regulation in the healthy sleep group compared to the sleep-restricted one. The quality of evidence was rated as high for the randomized trials. Among the 11 longitudinal studies, 8 reported that longer sleep was associated with better emotional regulation at follow-up (Barlett et al. 2012; Frederiksen et al. 2004; Roberts and Duong 2014; Roberts et al. 2009; Kalak et al. 2014; Pasch et al. 2012; Lin and Yi 2015; Lumeng et al. 2007) while 3 reported no association (Asarnow et al. 2014; Chang and Gable 2013; Silva et al. 2011). Given that only one study used an objective assessment of sleep duration (Silva et al. 2011), the quality of evidence was downgraded from low to very low (serious risk of bias). Among the 47 cross-sectional studies, 37 reported that longer sleep was related to better emotional regulation, 8 reported null findings, and 2 reported opposite associations. The quality of evidence was downgraded from low to very low due to a serious risk of bias (i.e. most studies used a subjective assessment of sleep with no psychometric properties reported).

\section{Cognition/Academic Achievement}

A total of 6 studies examined the association between sleep duration and cognition (e.g. concentration and memory) (Table 3 and Supplementary Table S1). Only one randomized trial examined this association (Vriend et al. 2013) and found that short term memory, working memory, divided attention and math fluency scores were lower in children in the short sleep 
condition ( $1 \mathrm{~h}$ later in bed for 4 nights with usual wake-up time) compared to long sleep ( $1 \mathrm{~h}$ earlier for 4 nights relative to their typical bedtime). However, no differences were found for reaction time on alerting, orienting, sustained or executive attention tasks between long and short sleep conditions. Due to serious imprecision (small effect sizes and only one study), we downgraded the quality of evidence from high to moderate. The only longitudinal study (Silva et al. 2011) reported no increased odds of having learning problems across sleep duration categories. The quality of evidence for this study design was downgraded from low to very low because only one study was published (serious imprecision). Finally, the four cross-sectional studies reported either positive, negative, or null findings (Kim et al. 2011; McClure et al. 2014; Ortega et al. 2010; van der Heijden et al. 2013). The quality of evidence was downgraded from low to very low due to a serious risk of bias (all studies used a subjective assessment of sleep with no psychometric properties reported) and serious inconsistency (mixed findings observed).

With regard to the association between sleep duration and academic achievement (Table 4 and Supplementary Table S1), 3 out of 4 longitudinal studies reported poorer grades with short sleep duration (Fredriksen et al. 2004; Roberts et al. 2009; Lin et al. 2015). However, Asarnow et al. (2014) reported that short sleep duration did not predict cumulative Grade Point Average at follow-up. The quality of evidence was downgraded from low to very low due to a serious risk of bias (all studies used a subjective assessment of sleep with no psychometric properties reported). Among the 17 cross-sectional studies, 11 showed associations for longer sleep duration and better academic achievement, or shorter sleep duration and poorer academic achievement, while the other studies reported either null $(n=5)$ or opposite $(n=1)$ findings. The quality of evidence was downgraded from low to very low due to a serious risk of bias (most studies used a 
subjective assessment of sleep with no psychometric properties reported) and serious indirectness (only half of the studies assessed children's actual grades or test results). Quality of Life/Well-Being

Only 3 studies examined the relationship between sleep duration and quality of life/well-being (Table 5 and Supplementary Table S1). The longitudinal study by Roberts et al. (2009) showed that participants with short sleep duration $(\leq 6 \mathrm{~h})$ at baseline had increased odds of low life satisfaction at 1 -year follow-up $(\mathrm{OR}=1.73,95 \% \mathrm{CI}$ : 1.17-1.54). The quality of evidence was downgraded from low to very low for this study design because of a serious risk of bias (sleep duration was self-reported with no psychometric properties reported) and serious imprecision (only one study was published so the risk of imprecision is high). Both cross-sectional studies (Perkinson-Gloor et al. 2013; Do et al. 2013) reported better quality of life and well-being with longer sleep duration. The quality of evidence was downgraded from low to very low due to a serious risk of bias (both studies relied on self-reported sleep with no psychometric properties reported).

\section{Harms/Injuries}

A total of 4 studies looked at the association between sleep duration and harms/injuries (one longitudinal, one cross-sectional and two case-control studies) (Table 6 and Supplementary Table S1). The longitudinal study showed that children who slept $<10 \mathrm{~h} /$ night at age 7 had greater odds of migraine but not tension-type headache at age 11 (Waldie et al. 2014). The quality of evidence was downgraded from low to very low due to serious imprecision (only one study). The cross-sectional study showed that adolescents who slept $<7 \mathrm{~h} /$ night did not have greater odds of single-injury compared to those who slept $\geq 7 \mathrm{~h} /$ night (Lam and Yang 2007). However, adolescents who slept $<7 \mathrm{~h} /$ night were more likely to have experienced multiple 
episodes of injury during the 3 months prior to the survey compared to those who slept $\geq 7$ $\mathrm{h} /$ night. The quality of evidence was downgraded from low to very low because of a serious risk of bias (sleep duration was self-reported with no psychometric properties reported) and serious imprecision (only one study). Finally, the two case-control studies reported different findings. Raffi et al. (2013) found that sleep duration was shorter in the injury group compared to the noninjury group, while Li et al. (2008) showed no difference in sleep duration in the case vs. control groups. Here again, the quality of evidence was downgraded from low to very low due to a serious risk of bias (sleep duration was self-reported in both studies with no psychometric properties reported).

\section{Cardiometabolic Biomarkers}

A total of 19 studies investigated the association between sleep duration and various cardiometabolic biomarkers (Table 7 and Supplementary Table S1). The 3 longitudinal studies included in this review (Hjorth et al. 2014a; Hancox and Landhuis 2012; Archbold et al. 2012) reported mixed findings (either short sleep associated with adverse cardiometabolic biomarkers or null findings). The quality of evidence was rated as low. Finally, the 16 cross-sectional studies also reported mixed findings. The quality of evidence was downgraded from low to very low because of a serious risk of bias (most studies used a subjective assessment of sleep duration with no psychometric properties reported) and serious inconsistency (positive, negative, or null findings).

A high-level summary of findings by health outcome can also be found in Table 8 . 


\section{Discussion}

This systematic review synthesized peer-reviewed evidence from 141 articles examining the relationships between sleep duration and a broad range of health indicators in children and youth age 5-17 years. A total of 1,241,056 participants from 40 different countries were represented in this review ( $\mathrm{n}=592,215$ participants from unique samples). The overall quality of evidence ranged from very low to high across study designs and health indicators. Collectively, the preponderance of the evidence suggests that shorter sleep duration is associated with adverse physical and mental health in children and youth (i.e. excess adiposity, poorer emotional regulation and academic achievement, and lower quality of life/well-being). This comprehensive assessment of available evidence highlights the need for continued efforts promoting the importance of a good night's sleep for overall health. It also highlights the need for higher quality studies with the hope of better informing sleep duration recommendations for children and youth.

An important observation of the available evidence in this field of research is the lack of use of objective measures for sleep duration. Among the 141 studies included in this systematic review, only $27(19 \%)$ had an objective assessment of sleep duration. Although polysomnography is considered the gold standard technique in laboratory experiments, actigraphy is gaining popularity for the assessment of sleep in epidemiologic research (Meltzer et al. 2012). While actigraphy can have its own challenges, it generally provides a good objective estimate of sleep duration (Sadeh 2011). In contrast, sleep questions typically used in epidemiologic studies do not agree very well with objective measures of sleep as assessed using actigraphy (Girschik et al. 
2012). This can certainly have implications for studies that are using self-reported sleep and it emphasizes the need for more accurate measures of sleep duration in future studies.

Another observation is the lack of studies examining the association between sleep duration and health indicators such as quality of life/well-being and harms/injuries in children and youth. One explanation is that the majority of research looking at these relationships is done in the adult population. Additionally, the inclusion criteria used for the present systematic review ( $\mathrm{n} \geq 300$ participants for observational studies and $n \geq 30$ participants for intervention studies) may have resulted in the exclusion of a number of studies in this area with smaller samples. We also excluded clinical populations from the present review (e.g. patients with sleep disorders such as insomnia or obstructive sleep apnea). It is well-known that these individuals have a higher risk of accidents and reduced quality of life in general (Gruber et al. 2014), which suggests an association between sleep duration/quality and these health indicators, although whether these relationships can be extrapolated to apparently healthy populations is unclear.

Inclusion/exclusion criteria were made $a$ priori by a group of experts in the field with an objective to determine the optimal amount of sleep that is associated with improved health outcomes in apparently healthy children and youth. As a result, limiting the sample size of included studies allowed for inclusion of a broader range of health outcomes while keeping the review manageable.

As discussed earlier, an objective of this article was to examine if the current sleep duration recommendations issued by the National Sleep Foundation are consistent with the best available evidence. The National Sleep Foundation recommends between 9-11 hours of sleep per night for 
school-aged children (ages 6-13 years) and 8-10 hours of sleep per night for adolescents (ages 14-17 years) in order to maximize overall health and well-being (Hirshkowitz et al. 2015). The National Sleep Foundation convened a multidisciplinary expert panel to evaluate the latest scientific evidence, including a consensus and voting process. Then, the RAND/UCLA Appropriateness Method was used to formulate sleep duration recommendations. A clear observation is that the best available evidence that can inform the sleep duration recommendations is weak, suggesting that expert opinion is needed until we have more research. There is a clear need for sleep restriction/extension interventions in children and youth that try to determine upper and lower limits of healthy sleep duration (i.e. dose-response curve). Although current sleep recommendations tend to suggest that a generalized optimum exists for the population, it is possible that different optimal sleep durations exist for different health outcomes (Matricciani et al. 2013). There is also inter-individual variability in sleep needs (e.g. due to genetic differences or sociocultural contexts) and sleeping longer or shorter than the recommended times may not necessarily mean that it will adversely affect health. However, individuals with sleep durations far outside the normal range may be engaging in behavioural sleep restriction or may have other health problems. Intentionally restricting sleep duration over a prolonged period of time may compromise overall health (Hirshkowitz et al. 2015).

Sleep duration recommendations provide ranges and imply that there is a U-shaped relationship between sleep time and health outcomes. While this is more evident in adults, a majority of studies included in this systematic review (especially with adiposity as the outcome measure) showed that more sleep is better. However, not all studies used categories of sleep duration and were not able to examine this issue. Also, some studies had small variability in sleep durations so 
there was inadequate resolution to assess whether "long sleep" was associated with adverse health outcomes. It is increasingly recognized that the two peaks of the U-shaped association between sleep and health outcomes do not mean the same thing (Knutson and Turek 2006). While short sleep is consistently associated with adverse health outcomes, long sleep is generally associated with other health problems that may confound the association. This further highlights the need to rely on objective assessments of sleep because time in bed does not necessarily reflect actual sleep duration. There is also the possibility of displacing other behaviours if one spends too much time in bed (e.g. less time for physical activity). Thus, it appears logical to have a range of "healthy" or "optimal" sleep duration from a population health standpoint.

It is also important to remember that the present systematic review focused on sleep duration only. However, an assessment of optimal sleep reaches well beyond the notion of sleep quantity, and includes sleep quality (i.e. efficiency of staying asleep), timing (i.e. bedtime/wake up time), architecture (i.e. sleep stages), consistency (i.e. day-to-day variability), and continuity (i.e. variability in sleep duration within the same night). Furthermore, a constraint of such a large review is that it precludes a detailed analysis (e.g. trends related to age, sex differences, possibility of conflicting results depending on the sleep assessment used, etc.). It is also wellknown that self-reported sleep duration overestimates actual sleep duration compared with objective measures. This can have important implications for sleep duration recommendations if future studies rely more heavily on objective assessments of sleep, because it will result in different sleep duration optima (i.e. lower for the objective measure and higher for the subjective measure). However, if parents and their children/youth are key targets for the sleep duration 
recommendations, it is more likely that they will use time in bed as their estimation of sleep duration.

In conclusion, the present article was the first to systematically examine the associations between sleep duration and such a large range of health indicators in children and youth. We confirmed previous investigations showing that shorter sleep duration is associated with adverse physical and mental health outcomes; however, the available evidence relies heavily on cross-sectional studies using self-reported sleep duration. In order to better inform contemporary sleep recommendations, there is an urgent need for sleep restriction/extension interventions in children and youth that examine the changes in different outcome measures against various amounts of sleep to have a better idea of dose-response relationships.

\section{Acknowledgements}

This study has been made possible through funding from the Canadian Society for Exercise Physiology, Healthy Active Living and Obesity Research Group from the Children's Hospital of Eastern Ontario Research Institute, Conference Board of Canada, and the Public Health Agency of Canada.

\section{Conflict of Interest Disclaimer}

The authors declare that there are no conflicts of interest. 


\section{References}

Al-Hazzaa, H.M. 2014. Joint associations of body mass index and waist-to-height ratio with sleep duration among Saudi adolescents. Annals of Human Biology, 41(2): 111-117.

Al-Hazzaa, H.M., Musaiger, A.O., Abahussain, N.A., Al-Sobayel, H.I., and Qahwaji, D.M. 2012. Prevalence of short sleep duration and its association with obesity among adolescents 15to 19-year olds: A cross-sectional study from three major cities in Saudi Arabia. Annals of Thoracic Medicine, 7(3): 133-139.

Akerstedt, T., and Nilsson, P.M. 2003. Sleep as restitution: an introduction. Journal of Internal Medicine 254 (1): 6-12.

Araujo, J., Severo, M., and Ramos, E. 2012. Sleep duration and adiposity during adolescence. Pediatrics, 130(5): e1146-e1154.

Arbabi, T., Vollmer, C., Dorfler, T., and Randler, C. 2015. The influence of chronotype and intelligence on academic achievement in primary school is mediated by conscientiousness, midpoint of sleep and motivation. Chronobiology International, 32(3): 349-357.

Archbold, K.H., Vasquez, M.M., Goodwin, J.L., and Quan, S.F. 2012. Effects of sleep patterns and obesity on increases in blood pressure in a 5-year period: report from the Tucson Children's Assessment of Sleep Apnea Study. Journal of Pediatrics, 161(1): 26-30.

Arman, A.R., Ay, P., Fis, N.P., Ersu, R., Topuzoglu, A., Isik, U., and Berkem, M. 2011. Association of sleep duration with socio-economic status and behavioural problems among schoolchildren. Acta Paediatrica, 100(3): 420-424.

Asarnow, L.D., McGlinchey, E., and Harvey, A.G. 2014. The effects of bedtime and sleep duration on academic and emotional outcomes in a nationally representative sample of adolescents. Journal of Adolescent Health, 54(3): 350-356.

Awad, K.M., Drescher, A.A., Malhotra, A., and Quan, S.F. 2013. Effects of exercise and nutritional intake on sleep architecture in adolescents. Sleep \& Breathing, 17(1): 117-124.

Barlett, N.D., Gentile, D.A., Barlett, C.P., Eisenmann, J.C., and Walsh, D.A. 2012. Sleep as a mediator of screen time effects on US children's health outcomes: A prospective study. Journal of Children and Media, 6(1): 37-50.

Barnes, J. 2015. The impact of sleep duration on adolescent development: A genetically informed analysis of identical twin pairs. Journal of Youth and Adolescence, 44(2): 489-506.

Baum, K.T., Desai, A., Field, J., Miller, L.E., Rausch, J., and Beebe, D.W. 2014. Sleep restriction worsens mood and emotion regulation in adolescents. Journal of Child Psychology \& Psychiatry \& Allied Disciplines, 55(2): 180-190. 
Bawazeer, N.M., Al-Daghri, N.M., Valsamakis, G., Al-Rubeaan, K.A., Sabico, S.L., Huang, T.T., Mastorakos, G.P., and Kumar, S. 2009. Sleep duration and quality associated with obesity among Arab children. Obesity, 17(12): 2251-2253.

Bel, S., Michels, N., De Vriendt, T., Patterson, E., Cuenca-Garcia, M., Diethelm, K., Gutin, B., Grammatikaki, E., Manios, Y., Leclercq, C., Ortega, F.B., Moreno, L.A., Gottrand, F., GonzalezGross, M., Widhalm, K., Kafatos, A., Garaulet, M., Molnar, D., Kaufman, J.M., Gilbert, C.C., Hallstrom, L., Sjostrom, M., Marcos, A., De Henauw, H.S., Huybrechts, I.; HELENA Study Group. 2013. Association between self-reported sleep duration and dietary quality in European adolescents. British Journal of Nutrition, 110(5): 949-959.

Berentzen, N.E., Smit, H.A., and Bekkers, M.B. 2014. Time in bed, sleep quality and associations with cardiometabolic markers in children: The prevention and incidence of asthma and mite allergy birth cohort study. Journal of Sleep Research, 23(1): 3-12.

Biggs, S.N., Lushington, K., van den Heuvel, C.J., and Martin, A. 2011. Inconsistent sleep schedules and daytime behavioral difficulties in school-aged children. Sleep Medicine, 12(8): $780-786$.

Bos, S.C., Gomes, A., Clemente, V., Marques, M., Pereira, A.T., Maia, B., Soares, M.J., Cabral, A.S., Macedo, A., Gozal, D., and Azavedo, M.H. 2009. Sleep and behavioral/emotional problems in children: A population-based study. Sleep Medicine, 10(1): 66-74.

Boschloo, A., Krabbendam, L., Dekker, S., Lee, N., de Groot, G.R., and Jolles, J. 2013. Subjective sleepiness and sleep quality in adolescents are related to objective and subjective measures of school performance. Frontiers in Psychology, 4(38): 1-5.

Butte, N.F., Puyau, M.R., Adolph, A.L., Vohra, F.A., and Zakeri, I. 2007. Physical activity in nonoverweight and overweight Hispanic children and adolescents. Medicine \& Science in Sports \& Exercise, 39(8): 1257-1266.

Calamaro, C.J., Park, S., and Mason, T.B. 2010. Shortened sleep duration does not predict obesity in adolescents. Journal of Sleep Research, 19(4): 559-566.

Chang, Y., and Gable, S. 2013. Predicting weight status stability and change from fifth grade to eighth grade: the significant role of adolescents' social-emotional well-being. Journal of Adolescent Health, 52(4): 448-455.

Chaput, J.P., Lambert, M., Gray-Donald, K., McGrath, J.J., Tremblay, M.S., O’Loughlin, J., and Tremblay, A. 2011. Short sleep duration is independently associated with overweight and obesity in Quebec children. Canadian Journal of Public Health, 102(5): 369-374.

Chaput, J.P., Leduc, G., Boyer, C., Belanger, P., LeBlanc, A.G., Borghese, M.M., and Tremblay, M.S. 2014. Objectively measured physical activity, sedentary time and sleep duration: independent and combined associations with adiposity in Canadian children. Nutrition \& Diabetes, 4: e117. 
Chen, M.Y., Wang, E.K., and Jeng, Y.J. 2006. Adequate sleep among adolescents is positively associated with health status and health-related behaviors. BMC Public Health, 6(59): 14712458.

Colley, R.C., Wong, S.L., Garriguet, D., Janssen, I., Connor Gorber, S., and Tremblay, M.S. 2012. Physical activity, sedentary behaviour and sleep in Canadian children: parent-report versus direct measures and relative associations with health risk. Health Reports, 23(2): 45-52.

Culnan, E., Holliday, S.B., Daly, B.P., Aggarwal, R., and Kloss, J.D. 2013. Insufficient sleep and weight status in high school students: Should we be focusing on the extremes? Children's Health Care, 42(2): 99-115.

Dagys, N., McGlinchey, E.L., Talbot, L.S., Kaplan, K.A., Dahl, R.E., and Harvey, A.G. 2012. Double trouble? The effects of sleep deprivation and chronotype on adolescent affect. Journal of Child Psychology and Psychiatry, 53(6): 660-667.

Danielsen, Y.S., Pallesen, S., Stormark, K.M., Nordhus, I.H., and Bjorvatn, B. 2010. The relationship between school day sleep duration and body mass index in Norwegian children (aged 10-12). International Journal of Pediatric Obesity, 5(3): 214-220.

de Jong, E., Stocks, T., and Visscher, T. 2012. Association between sleep duration and overweight: the importance of parenting. International Journal of Obesity, 36(10): 1278-1284.

de Souza, C.M., and Hidalgo, M.P.L. 2014. Midpoint of sleep on school days is associated with depression among adolescents. Chronobiology International, 31(2): 199-205.

Dewald, J.F., Short, M.A., Gradisar, M., Oort, F.J., and Meijer, A.M. 2012. The Chronic Sleep Reduction Questionnaire (CSRQ): a cross-cultural comparison and validation in Dutch and Australian adolescents. Journal of Sleep Research, 21(5): 584-594.

Dewald-Kaufmann, J.F., Oort, F.J., Bogels, S., and Meijer, M. 2013. Why sleep matters: differences in daytime functioning between adolescents with low and high chronic sleep reduction and short and long sleep durations. Journal of Cognitive and Behavioral Psychotherapies, 13(1a):171-182.

Do, Y.K., Shin, E., Bautista, M.A., and Foo, K. 2013. The associations between self-reported sleep duration and adolescent health outcomes: what is the role of time spent on Internet use? Sleep Medicine, 14(2): 195-200.

Eide, E.R., and Showalter, M.H. 2012. Sleep and student achievement. Eastern Economic Journal, 38: 512-524.

Eisenmann, J.C., Ekkekakis, P., and Holmes, M. 2006. Sleep duration and overweight among Australian children and adolescents. Acta Paediatrica, 95(8): 956-963. 
Ekstedt, M., Nyberg, G., Ingre, M., Ekblom, O., and Marcus, C. 2013. Sleep, physical activity and BMI in six to ten-year-old children measured by accelerometry: a cross-sectional study. International Journal of Behavioral Nutrition and Physical Activity, 10: 82.

Fitzgerald, C.T., Messias, E., and Buysse, D.J. 2011. Teen sleep and suicidality: results from the youth risk behavior surveys of 2007 and 2009. Journal of Clinical Sleep Medicine, 7(4): 351356.

Fredriksen, K., Rhodes, J., Reddy, R., and Way, N. 2004. Sleepless in Chicago: Tracking the Effects of Adolescent Sleep Loss During the Middle School Years. Child Development, 75(1): 84-95.

Gangwisch, J.E., Babiss, L.A., Malaspina, D., and Turner, J. 2010. Earlier parental set bedtimes as a protective factor against depression and suicidal ideation. Sleep: Journal of Sleep and Sleep Disorders Research, 33(1): 97-106.

Garaulet, M., Ortega, F.B., Ruiz, J.R., Rey-Lopez, J.P., Beghin, L., Manios, Y., Cuenca-Garcia, M., Plada, M., Diethelm, K., Kafatos, A., Molnar, D., Al-Tahan, J., and Moreno, L.A. 2011. Short sleep duration is associated with increased obesity markers in European adolescents: effect of physical activity and dietary habits. The HELENA study. International Journal of Obesity, 35(10): 1308-1317.

Girschik, J., Fritschi, L., Heyworth, J., and Waters, F. 2012. Validation of self-reported sleep against actigraphy. Journal of Epidemiology, 22(5):462-468.

Gruber, R., Carrey, N., Weiss, S.K., Frappier, J.Y., Rourke, L., Brouillette, R.T., and Wise, M.S. 2014. Position statement on pediatric sleep for psychiatrists. Journal of the Canadian Academy of Child and Adolescent Psychiatry, 23(3): 174-195.

Guyatt, G.H., Oxman, A.D., Vist, G., Kunz, R., Brozek, J., Alonso-Coello, P., Montori, V., Akl, E.A., Djulbegovic, B., Falck-Ytter, Y., Norris, S.L., Williams Jr., J.W., Atkins, D., Meerpohl, J., and Schünemann, H.J. 2011. GRADE guidelines: 4. Rating the quality of evidence - study limitations (risk of bias). Journal of Clinical Epidemiology, 64(4): 407-415.

Guo, X., Zheng, L., Li, Y., Yu, S., Sun, G., Yang, H., Zhou, X., Zhang, X., Sun, Z., and Sun, Y. 2012. Differences in lifestyle behaviors, dietary habits, and familial factors among normalweight, overweight, and obese Chinese children and adolescents. International Journal of Behavioral Nutrition and Physical Activity, 9: 120.

Gupta, N.K., Mueller, W.H., Chan, W., and Meininger, J.C. 2002. Is obesity associated with poor sleep quality in adolescents? American Journal of Human Biology, 14(6): 762-768.

Hancox, R.J., and Landhuis, C.E. 2012. Association between sleep duration and haemoglobin A1c in young adults. Journal of Epidemiology and Community Health, 66(10): 957-961. 
Hart, C.N., Carskadon, M.A., Considine, R.V., Fava, J.L., Lawton, J., Raynor, H.A., Jelalian, E., Owens, J., and Wing, R. 2013. Changes in children's sleep duration on food intake, weight, and leptin. Pediatrics, 132(6): e1473-e1480.

Hense, S., Pohlabeln, H., De Henauw, S., Eiben, G., Molnar, D., Moreno, L.A., Barba, G., Hadjigeorgiou, C., Veidebaum, T., and Ahrens, W. 2011. Sleep duration and overweight in European children: Is the association modified by geographic region? Sleep, 34(7): 885-890.

Higgins, J., and Green, S. 2011. Cochrane Handbook for Systematic Reviews of Interventions Version 5.1.0. The Cochrane Collaboration. Available from www.cochrane-handbook.org (accessed 23 October 2015).

Hirshkowitz, M., Whiton, K., Albert, S.M., Alessi, C., Bruni, O., DonCarlos, L., Hazen, N., Herman, J., Katz, E.S., Kheirandish-Gozal, L., Neubauer, D.N., O’Donnell, A.E., Ohayon, M., Peever, J., Rawding, R., Sachdeva, R.C., Setters, B., Vitiello, M.V., and Ware, J.C. 2015. National Sleep Foundation's sleep time duration recommendations: methodology and results summary. Sleep Health, 1(1): 40-43.

Hiscock, H., Scalzo, K., Canterford, L., and Wake, M. 2011. Sleep duration and body mass index in 0-7-year olds. Archives of Disease in Childhood, 96(8): 735-739.

Hitze, B., Bosy-Westphal, A., Bielfeldt, F., Settler, U., Plachta-Danielzik, S., Pfeuffer, M., Schrezenmeir, J., Monig, H., and Muller, M.J. 2009. Determinants and impact of sleep duration in children and adolescents: data of the Kiel Obesity Prevention Study. European Journal of Clinical Nutrition, 63(6): 739-746.

Hjorth, M.F., Chaput, J.P., Damsgaard, C.T., Dalskov, S.M., Andersen, R., Astrup, A., Michaelsen, K.F., Tetens, I., Ritz, C., and Sjodin, A. 2014a. Low physical activity level and short sleep duration are associated with an increased cardio-metabolic risk profile: a longitudinal study in 8-11 year old Danish children. PLoS ONE, 9(8): e104677.

Hjorth, M.F., Chaput, J.P., Ritz, C., Dalskov, S.M., Andersen, R., Astrup, A., Tetens, I., Michaelsen, K.F., and Sjodin, A. 2014b. Fatness predicts decreased physical activity and increased sedentary time, but not vice versa: support from a longitudinal study in 8- to 11-yearold children. International Journal of Obesity, 38(7): 959-965.

Huang, Y.S., Wang, C.H., and Guilleminault, C. 2010. An epidemiologic study of sleep problems among adolescents in North Taiwan. Sleep Medicine, 11(10): 1035-1042.

Ievers-Landis, C.E., Storfer-Isser, A., Rosen, C., Johnson, N.L., and Redline, S. 2008. Relationship of sleep parameters, child psychological functioning, and parenting stress to obesity status among preadolescent children. Journal of Developmental and Behavioral Pediatrics, 29(4): 243-252.

Javaheri, S., Storfer-Isser, A., Rosen, C.L., and Redline, S. 2011. Association of short and long sleep durations with insulin sensitivity in adolescents. Journal of Pediatrics, 158(4): 617-623. 
Kalak, N., Lemola, S., Brand, S., Holsboer-Trachsler, E., and Grob, A. 2014. Sleep duration and subjective psychological well-being in adolescence: A longitudinal study in Switzerland and Norway. Neuropsychiatric Disease and Treatment, 10: 1199-1207.

Katzmarzyk, P.T., Barreira, T.V., Broyles, S.T., Champagne, C.M., Chaput, J.P., Fogelholm, M., Hu, G., Johnson, W.D., Kuriyan, R., Kurpad, A., Lambert, E.V., Maher, C., Maia, J., Matsudo, V., Olds, T., Onywera, V., Sarmiento, O.L., Standage, M., Tremblay, M.S., Tudor-Locke, C., Zhao, P., and Church, T.S. 2015. Relationships between lifestyle behaviors and obesity in children ages 9-11: Results from a 12-country study. Obesity, 23(8): 1696-1702.

Kang, S.G., Lee, Y.J., Kim, S.J., Lim, W., Lee, H.J., Park, Y.M., Cho, I.H., Cho, S.J., and Hong, J.P. 2014. Weekend catch-up sleep is independently associated with suicide attempts and selfinjury in Korean adolescents. Comprehensive Psychiatry, 55(2): 319-325.

Keyes, K.M., Maslowsky, J., Hamilton, A., Schulenberg, J. 2015. The Great Sleep Recession: changes in sleep duration among US adolescents, 1991-2012. Pediatrics, 135(3): 460-468.

Kim, S.J., Lee, Y.J., Cho, S.J., Cho, I.H., Lim, W., and Lim, W. 2011. Relationship between weekend catch-up sleep and poor performance on attention tasks in Korean adolescents.

Archives of Pediatrics \& Adolescent Medicine, 165(9): 806-812.

Knight-Eily, L.R., Eaton, D.K., Lowry, R., Croft, J.B., Presley-Cantrell, L., and Perry, G.S. 2011. Relationships between hours of sleep and health-risk behaviors in US adolescent students. Preventive Medicine, 53(4-5): 271-273.

Knutson, K.L. 2005. Sex differences in the association between sleep and body mass index in adolescents. Journal of Pediatrics, 147(6): 830-834.

Knutson, K.L., and Lauderdale, D.S. 2007. Sleep duration and overweight in adolescents: selfreported sleep hours versus time diaries. Pediatrics, 119(5): e1056-e1062.

Knutson, K.L., and Turek, F.W. 2006. The U-shaped association between sleep and health: the 2 peaks do not mean the same thing. Sleep, 29(7):878-879.

Kong, A.P., Wing, Y.K., Choi, K.C., Li, A.M., Ko, G.T., Ma, R.C., Tong, P.C., Ho, C.S., Chan, M.H., Ng, M.H., Lau, J., and Chan, J.C. 2011. Associations of sleep duration with obesity and serum lipid profile in children and adolescents. Sleep Medicine, 12(7): 659-665.

Kubiszewski, V., Fontaine, R., Potard, C., and Gimenes, G. 2014. Bullying, sleep/wake patterns and subjective sleep disorders: findings from a cross-sectional survey. Chronobiology International, 31(4): 542-553.

Kuciene, R., and Dulskiene, V. 2014. Associations of short sleep duration with prehypertension and hypertension among Lithuanian children and adolescents: a cross-sectional study. BMC Public Health, 14: 255. 
Lam, L.T., and Yang, L. 2008. Duration of sleep and ADHD tendency among adolescents in China. Journal of Attention Disorders, 11(4): 437-444

Lam, L.T., and Yang, L. 2007. Short duration of sleep and unintentional injuries among adolescents in China. American Journal of Epidemiology, 166(9): 1053-1058.

Lee, J.A., and Park, H.S. 2014. Relation between sleep duration, overweight, and metabolic syndrome in Korean adolescents. Nutrition Metabolism \& Cardiovascular Diseases, 24(1): 6571.

Lee, Y.J., Cho, S.J., Cho, I.H., and Kim, S.J. 2012. Insufficient sleep and suicidality in adolescents. Sleep, 35(4): 455-460.

Lehto, J.E., and Uusitalo-Malmivaara, L. 2014. Sleep-related factors: associations with poor attention and depressive symptoms. Child: Care, Health \& Development, 40(3): 419-425.

Lemola, S., Perkinson-Gloor, N., Brand, S., wald-Kaufmann, J.F., and Grob, A. 2015. Adolescents' electronic media use at night, sleep disturbance, and depressive symptoms in the smartphone age. Journal of Youth \& Adolescence, 44(2): 405-418.

Li, Y., Jin, H., Owens, J.A., and Hu, C. 2008. The association between sleep and injury among school-aged children in rural China: a case-control study. Sleep Medicine, 9(2): 142-148.

Lin, J.D., Tung, H.J., Hsieh, Y.H., and Lin, F.G. 2011. Interactive effects of delayed bedtime and family-associated factors on depression in elementary school children. Research in Developmental Disabilities, 32(6): 2036-2044.

Lin, W.H., and Yi, C.C. 2015. Unhealthy sleep practices, conduct problems, and daytime functioning during adolescence. Journal of Youth and Adolescence, 44(2): 431-446.

Liou, Y.M., Liou, T.H., and Chang, L.C. 2010. Obesity among adolescents: sedentary leisure time and sleeping as determinants. Journal of Advanced Nursing, 66(6): 1246-1256.

Liu, X. 2004. Sleep and Adolescent Suicidal Behavior. Sleep: Journal of Sleep and Sleep Disorders Research, 27(7): 1351-1358.

Liu, X., and Zhou, H. 2002. Sleep duration, insomnia and behavioral problems among Chinese adolescents. Psychiatry Research, 111(1): 75-85.

Lowry, R., Eaton, D.K., Foti, K., Knight-Eily, L., Perry, G., and Galuska, D.A. 2012.

Association of sleep duration with obesity among US high school students. Journal of Obesity, 2012: 476914.

Lumeng, J.C., Somashekar, D., Appugliese, D., Kaciroti, N., Corwyn, R.F., and Bradley, R.H. 2007. Shorter sleep duration is associated with increased risk for being overweight at ages 9 to 12 years. Pediatrics, 120(5): 1020-1029. 
Lytle, L.A., Murray, D.M., Laska, M.N., Pasch, K.E., Anderson, S.E., and Farbakhsh, K. 2013. Examining the longitudinal relationship between change in sleep and obesity risk in adolescents. Health Education \& Behavior, 40(3): 362-370.

Magee, C.A., Caputi, P., and Iverson, D.C. 2013a. Patterns of health behaviours predict obesity in Australian children. Journal of Paediatrics \& Child Health, 49(4): 291-296.

Magee, C.A., Caputi, P., and Iverson, D.C. 2013b. The longitudinal relationship between sleep duration and body mass index in children: A growth mixture modeling approach. Journal of Developmental and Behavioral Pediatrics, 34(3): 165-173.

Martinez, S.M., Greenspan, L.C., Butte, N.F., Gregorich, S.E., De Groat, C.L., Deardorff, J., Penilla, C., Pasch, L.A., Flores, E., and Tschann, J.M. 2014. Mother-reported sleep, accelerometer-estimated sleep and weight status in Mexican American children: sleep duration is associated with increased adiposity and risk for overweight/obese status. Journal of Sleep Research, 23(3): 326-334.

Martinez-Gomez, D., Moreno, L.A., Romeo, J., Rey-Lopez, P., Castillo, R., Cabero, M.J., Vicente-Rodriguez, G., Gutierrez, A., and Veiga, O.L. 2011. Combined influence of lifestyle risk factors on body fat in Spanish adolescents - the Avena study. Obesity Facts, 4(2): 105-111.

Matricciani, L., Olds, T., and Petkov, J. 2012a. In search of lost sleep: secular trends in the sleep time of school-aged children and adolescents. Sleep Medicine Reviews, 16(3): 203-211.

Matricciani, L., Olds, T.S., Blunden, S., Rigney, G., and Williams, M.T. 2012b. Never enough sleep: a brief history of sleep recommendations for children. Pediatrics, 129(3):548-556.

Matricciani, L., Blunden, S., Rigney, G., Williams, M.T., and Olds, T.S. 2013. Children's sleep needs: is there sufficient evidence to recommend optimal sleep for children? Sleep, 36(4): 527534.

McClure, D.J., Zuckerman, S.L., Kutscher, S.J., Gregory, A.J., and Solomon, G.S. 2014. Baseline neurocognitive testing in sports-related concussions: the importance of a prior night's sleep. American Journal of Sports Medicine, 42(2): 472-478.

McHale, S.M., Kim, J.Y., Kan, M., and Updegraff, K.A. 2011. Sleep in Mexican-American adolescents: Social ecological and well-being correlates. Journal of Youth and Adolescence, 40(6): 666-679.

Meijer, A.M., Reitz, E., Dekovic, M., van den Wittenboer, G.L.H., and Stoel, R.D. 2010. Longitudinal relations between sleep quality time in bed and adolescent problem behaviour. Journal of Child Psychology and Psychiatry, 51(11): 1278-1286.

Meininger, J.C., Gallagher, M.R., Eissa, M.A., Nguyen, T.Q., and Chan, W. 2014. Sleep duration and its association with ambulatory blood pressure in a school-based, diverse sample of adolescents. American Journal of Hypertension, 27(7): 948-955. 
Meldrum, R.C., and Restivo, E. 2014. The behavioral and health consequences of sleep deprivation among U.S. high school students: Relative deprivation matters. Preventive Medicine, 63: 24-28.

Meltzer, L.J., Montgomery-Downs, H.E., Insana, S.P., and Walsh, C.M. 2012. Use of actigraphy for assessment in pediatric sleep research. Sleep Medicine Reviews, 16(5): 463-475.

Michels, N., Clays, E., De Buyzere, M., Vanaelst, B., De Henauw, S., and Sioen, I. 2013. Children's sleep and autonomic function: low sleep quality has an impact on heart rate variability. Sleep, 36(12): 1939-1946.

Mitchell, J.A., Rodriguez, D., Schmitz, K.H., and Audrain-McGovern, J. 2013. Sleep duration and adolescent obesity. Pediatrics, 131(5): e1428-e1434.

Moher, D., Liberati, A., Tetzlaff, J., and Altman, D.G. 2009. Preferred Reporting Items for Systematic Reviews and Meta-Analyses: The PRISMA Statement. Annals of Internal Medicine 151(4): 264-269.

Morley, B.C., Scully, M.L., Niven, P.H., Okely, A.D., Baur, L.A., Pratt, I.S., Wakefield, M.A., and NaSSDA Study Team. 2012. What factors are associated with excess body weight in Australian secondary school students? Medical Journal of Australia, 196(3): 189-192.

Narang, I., Manlhiot, C., Davies-Shaw, J., Gibson, D., Chahal, N., Stearne, K., Fisher, A., Dobbin, S., and McCrindle, B.W. 2012. Sleep disturbance and cardiovascular risk in adolescents. Canadian Medical Association Journal, 184(17): E913-E920.

Nixon, G.M., Thompson, J.M., Han, D.Y., Becroft, D.M., Clark, P.M., Robinson, E., Waldie, K.E., Wild, C.J., Black, P.N., and Mitchell, E.A. 2008. Short sleep duration in middle childhood: risk factors and consequences. Sleep, 31(1): 71-78.

O’Dea, J.A., and Mugridge, A.C. 2012. Nutritional quality of breakfast and physical activity independently predict the literacy and numeracy scores of children after adjusting for socioeconomic status. Health Education Research, 27(6): 975-985.

Ohayon, M.M. 2012. Determining the level of sleepiness in the American population and its correlates. Journal of Psychiatric Research, 46(4): 422-427.

Ortega, F., Ruiz, J., Castillo, R., Chillon, P., Labayen, I., Martinez-Gomez, D., Redondo, C., Marcos, A., and Moreno, L. 2010. Sleep duration and cognitive performance in adolescence. The AVENA study. Acta Paediatrica, 99(3): 454-456.

Owens, J.; Adolescent Sleep Working Group; Committee on Adolescence. 2014. Insufficient sleep in adolescents and young adults: an update on causes and consequences. Pediatrics, 134(3):e921-e932. 
Ozturk, A., Mazicioglu, M., Poyrazoglu, S., Cicek, B., Gunay, O., and Kurtoglu, S. 2009. The relationship between sleep duration and obesity in Turkish children and adolescents. Acta Paediatrica, 98(4): 699-702.

Paciencia, I., Barros, H., Araujo, J., and Ramos, E. 2013. Association between sleep duration and blood pressure in adolescents. Hypertension Research 36(8): 747-752.

Padez, C., Mourao, I., Moreira, P., and Rosado, V. 2009. Long sleep duration and childhood overweight/obesity and body fat. American Journal of Human Biology, 21: 371-376.

Pallesen, S., Saxvig, I.W., Molde, H., Sorensen, E., Wilhelmsen-Langeland, A., and Bjorvatn, B. 2011. Brief report: behaviorally induced insufficient sleep syndrome in older adolescents: prevalence and correlates. Journal of Adolescence, 34(2): 391-395.

Park, J.H., Yoo, J.H., and Kim, S.H. 2013. Associations between non-restorative sleep, short sleep duration and suicidality: Findings from a representative sample of Korean adolescents. Psychiatry and Clinical Neurosciences, 67(1): 28-34.

Park, S. 2012. The association between short sleep duration and body mass index among South Korean children and adolescents. Journal of School Nursing, 29(2): 142-150.

Park, S. 2011. Association between short sleep duration and obesity among South Korean adolescents. Western Journal of Nursing Research, 33(2): 207-223.

Pasch, K.E., Latimer, L.A., Cance, J.D., Moe, S.G., and Lytle, L.A. 2012. Longitudinal bidirectional relationships between sleep and youth substance use. Journal of Youth \& Adolescence, 41(9): 1184-1196.

Peach, H., Gaultney, J.F., and Reeve, C.L. 2015. Sleep characteristics, body mass index, and risk for hypertension in young adolescents. Journal of Youth and Adolescence, 44(2): 271-284.

Perez de Heredia, F., Garaulet, M., Gomez-Martinez, S., Diaz, L.E., Warnberg, J., Androutsos, O., Michels, N., Breidenassel, C., Cuenca-Garcia, M., Huybrechts, I., Gottrand, F., Ferrari, M., Santaliestra-Pasias, A.M., Kafatos, A., Molnar, D., Sjostrom, M., Widhalm, K., Moreno, L.A., Marcos, A.; HELENA Study Group. 2014. Self-reported sleep duration, white blood cell counts and cytokine profiles in European adolescents: the HELENA study. Sleep Medicine, 15(10): 1251-1258.

Perfect, M.M., Levine-Donnerstein, D., Archbold, K., Goodwin, J.L., and Quan, S.F. 2014. The contribution of sleep problems to academic and psychosocial functioning. Psychology in the Schools, 51(3): 273-295.

Perkinson-Gloor, N., Lemola, S., and Grob, A. 2013. Sleep duration, positive attitude toward life, and academic achievement: the role of daytime tiredness, behavioral persistence, and school start times. Journal of Adolescence, 36(2): 311-318. 
Quevedo-Blasco, V.J., and Quevedo-Blasco, R. 2011. Influence of drowsiness, quantity and quality of sleep in relation with academic performance in teenagers. International Journal of Clinical and Health Psychology, 11(1): 49-65.

Rafii, F., Oskouie, F., and Shoghi, M. 2013. The Association between sleep and injury among school-aged children in Iran. Sleep Disorders, 2013: 891090.

Rey-Lopez, J.P., de Carvalho, H.B., de Moraes, A.C., Ruiz, J.R., Sjostrom, M., Marcos, A., Polito, A., Gottrand, F., Manios, Y., Kafatos, A., Molnar, D., Widhalm, K., De Henauw, S., and Moreno, L.A.; HELENA study. 2014. Sleep time and cardiovascular risk factors in adolescents: the HELENA (Healthy Lifestyle in Europe by Nutrition in Adolescence) study. Sleep Medicine, 15(1): 104-110.

Roberts, R.E., and Duong, H.T. 2014. The prospective association between sleep deprivation and depression among adolescents. Sleep: Journal of Sleep and Sleep Disorders Research, 37(2): 239-244.

Roberts, R.E., Roberts, C.R., and Duong, H.T. 2009. Sleepless in adolescence: prospective data on sleep deprivation, health and functioning. Journal of Adolescence, 32(5): 1045-1057.

Rodriguez-Colon, S.M., He, F., Bixler, E.O., Fernandez-Mendoza, J., Vgontzas, A.N., Calhoun, S., Zheng, Z.J., and Liao, D. 2015. Sleep variability and cardiac autonomic modulation in adolescents - Penn State Child Cohort (PSCC) study. Sleep Medicine, 16(1): 67-72.

Sadeh, A. 2011. The role and validity of actigraphy in sleep medicine: an update. Sleep Medicine Reviews, 15(4):259-267.

Sarchiapone, M., Mandelli, L., Carli, V., Iosue, M., Wasserman, C., Hadlaczky, G., Hoven, C.W., Apter, A., Balazs, J., Bobes, J., Brunner, R., Corcoran, P., Cosman, D., Haring, C., Kaess, M., Keeley, H., Kereszteny, A., Kahn, J.P., Postuvan, V., Mars, U., Saiz, P.A., Varnik, P., Sisask, M., and Wasserman, D. 2014. Hours of sleep in adolescents and its association with anxiety, emotional concerns, and suicidal ideation. Sleep Medicine, 15(2): 248-254.

Schardt, C., Adams, M.B., Owens, T., Keitz, S., and Fontelo, P. 2007. Utilization of the PICO framework to improve searching PubMed for clinical questions. BMC Medical Informatics and Decision Making, 7: 16.

Scharf, R.J., and DeBoer, M.D. 2015. Sleep timing and longitudinal weight gain in 4- and 5year-old children. Pediatric Obesity, 10(2): 141-148.

Sekine, M., Yamagami, T., Handa, K., Saito, T., Nanri, S., Kawaminami, K., Tokui, N., Yoshida, K., and Kagamimori, S. 2001. A dose-response relationship between short sleeping hours and childhood obesity: results of the Toyama Birth Cohort Study. Child: Care, Health and Development, 28(2): 163-170. 
Shan, X.Y., Xi, B., Cheng, H., Hou, D.Q., Wang, Y., and Mi, J. 2010. Prevalence and behavioral risk factors of overweight and obesity among children aged 2-18 in Beijing, China. International Journal of Pediatric Obesity, 5(5): 383-389.

Short, M.A., Gradisar, M., Lack, L.C., and Wright, H.R. 2013a. The impact of sleep on adolescent depressed mood, alertness and academic performance. Journal of Adolescence, 36(6): 1025-1033.

Short, M.A., Gradisar, M., Lack, L.C., Wright, H.R., and Dohnt, H. 2013b. The sleep patterns and well-being of Australian adolescents. Journal of Adolescence, 36(1): 103-110.

Silva, G.E., Goodwin, J.L., Parthasarathy, S., Sherrill, D.L., Vana, K.D., Drescher, A.A., and Quan, S.F. 2011. Longitudinal association between short sleep, body weight, and emotional and learning problems in Hispanic and Caucasian children. Sleep, 34(9): 1197-1205.

Sivertsen, B., Pallesen, S., Sand, L., and Hysing, M. 2014a. Sleep and body mass index in adolescence: results from a large population-based study of Norwegian adolescents aged 16 to 19 years. BMC Pediatrics, 14: 204.

Sivertsen, B., Harvey, A.G., Lundervold, A.J., and Hysing, M. 2014b. Sleep problems and depression in adolescence: results from a large population-based study of Norwegian adolescents aged 16-18 years. European Child \& Adolescent Psychiatry, 23(8): 681-689.

Stea, T.H., Knutsen, T., and Torstveit, M.K. 2014. Association between short time in bed, healthrisk behaviors and poor academic achievement among Norwegian adolescents. Sleep Medicine, 15(6): 666-671.

Stroebele, N., McNally, J., Plog, A., Siegfried, S., and Hill, J.O. 2013. The association of selfreported sleep, weight status, and academic performance in fifth-grade students. Journal of School Health, 83(2): 77-84.

Suglia, S.F., Kara, S., and Robinson, W.R. 2014. Sleep duration and obesity among adolescents transitioning to adulthood: do results differ by sex? Journal of Pediatrics, 165(4): 750-754.

Suglia, S.F., Duarte, C.S., Chambers, E.C., and Boynton-Jarrett, R. 2013. Social and behavioral risk factors for obesity in early childhood. Journal of Developmental and Behavioral Pediatrics, 34(8): 549-556.

Suzuki, H., Kaneita, Y., Osaki, Y., Minowa, M., Kanda, H., Suzuki, K., Wada, K., Hayashi, K., Tanihata, T., and Ohida,T. 2011. Clarification of the factor structure of the 12-item General Health Questionnaire among Japanese adolescents and associated sleep status. Psychiatry Research, 188(1): 138-146.

Tamura, N., and Tanaka, H. 2014. Effects of sleep education with self-help treatment for elementary schoolchild with nocturnal lifestyle and irritability. Sleep and Biological Rhythms, 12(3): 169-179. 
Titova, O.E., Hogenkamp, P.S., Jacobsson, J.A., Feldman, I., Schioth, H.B., and Benedict, C. 2015. Associations of self-reported sleep disturbance and duration with academic failure in community-dwelling Swedish adolescents: sleep and academic performance at school. Sleep Medicine, 16(1): 87-93.

Unalan, D., Ozturk, A., Ismailogullari, S., Akgul, N., and Aksu, M. 2013. The effect of sleep duration and quality on academic success of the elementary school children in Kayseri Turkey. Journal of the Pakistan Medical Association, 63(5): 576-580.

Vaezghasemi, M., Lindkvist, M., Ivarsson, A., and Eurenius, E. 2012. Overweight and lifestyle among 13-15 year olds: a cross-sectional study in northern Sweden. Scandinavian Journal of Public Health, 40(3): 221-228.

van der Heijden, K.B., de Sonneville, L.M., and Swaab, H. 2013. Association of eveningness with problem behavior in children: a mediating role of impaired sleep. Chronobiology International, 30(7): 919-929.

van der Vinne, V., Zerbini, G., Siersema, A., Pieper, A., Merrow, M., Hut, R.A., Roenneberg, T., and Kantermann, T. 2015. Timing of examinations affects school performance differently in early and late chronotypes. Journal of Biological Rhythms, 30(1): 53-60.

von Kries, R., Toschke, A.M., Wurmser, H., Sauerwald, T., and Koletzko, B. 2002. Reduced risk for overweight and obesity in 5- and 6-y-old children by duration of sleep - a cross-sectional study. International Journal of Obesity, 26: 710-716.

Vriend, J.L., Davidson, F.D., Corkum, P.V., Rusak, B., Chambers, C.T., and McLaughlin, E.N. 2013. Manipulating sleep duration alters emotional functioning and cognitive performance in children. Journal of Pediatric Psychology, 38(10): 1058-1069.

Waldie, K.E., Thompson, J.M., Mia, Y., Murphy, R., Wall, C., and Mitchell, E.A. 2014. Risk factors for migraine and tension-type headache in 11 year old children. Journal of Headache \& Pain, 15: 60 .

Wang, G., Xu, G., Liu, Z., Lu, N., Ma, R., and Zhang, E. 2013. Sleep patterns and sleep disturbances among Chinese school-aged children: prevalence and associated factors. Sleep Medicine, 14(1): 45-52.

Wells, J. 2008. Sleep patterns and television viewing in relation to obesity and blood pressure: evidence from an adolescent Brazilian birth cohort. International Journal of Obesity, 32(7): 1042-1049.

Wing, Y.K., Li, S.X., Li, A.M., Zhang, J., and Kong, A.P. 2009. The effect of weekend and holiday sleep compensation on childhood overweight and obesity. Pediatrics, 124(5): e994e1000. 
Winsler, A., Deutsch, A., Vorona, R.D., Payne, P.A., and Szklo-Coxe, M. 2015. Sleepless in Fairfax: the difference one more hour of sleep can make for teen hopelessness, suicidal ideation, and substance use. Journal of Youth \& Adolescence, 44(2): 362-378.

Wolfson, A.R., and Carskadon, M.A. 1998. Sleep schedules and daytime functioning in adolescents. Child Development, 69(4): 875-887.

Wong, W.W., Ortiz, C.L., Lathan, D., Moore, L.A., Konzelmann, K.L., Adolph, A.L., Smith, E.O., and Butte, N.F. 2013. Sleep duration of underserved minority children in a cross-sectional study. BMC Public Health, 13: 648.

Yen, C.F., King, B.H., and Tang, T.C. 2010. The association between short and long nocturnal sleep durations and risky behaviours and the moderating factors in Taiwanese adolescents. Psychiatry Research, 179(1): 69-74. 
Table 1. Association between sleep duration and adiposity in children and youth.

\begin{tabular}{|c|c|c|c|c|c|c|c|c|c|}
\hline \multirow{2}{*}{$\begin{array}{l}\text { No of } \\
\text { studies }\end{array}$} & \multirow[t]{2}{*}{ Design } & \multicolumn{5}{|c|}{ Quality Assessment } & \multirow{2}{*}{$\begin{array}{c}\text { No of } \\
\text { participants }\end{array}$} & \multirow{2}{*}{ Absolute effect } & \multirow{2}{*}{ Quality } \\
\hline & & Risk of bias & Inconsistency & Indirectness & Imprecision & Other & & & \\
\hline \multicolumn{10}{|c|}{$\begin{array}{l}\text { Mean age ranged between } 5 \text { and } 17.7 \text { years. Intervention study was } 1 \text { week long and up to } 6 \text { years for longitudinal studies. Sleep duration was assessed by actigraphy, } \\
\text { polysomnography, parent report or self-report. Adiposity was assessed as body weight, body mass index (absolute, z-score or percentile), fat mass index, waist } \\
\text { circumference, waist-to-height ratio, weight status (different definitions for underweight, normal weight, overweight, obese) or \% body fat (bioelectrical impedance, } \\
\text { dual-energy X-ray absorptiometry, skinfolds), either objectively or subjectively. }\end{array}$} \\
\hline 1 & $\begin{array}{l}\text { Randomized } \\
\text { trial }^{\mathrm{a}}\end{array}$ & $\begin{array}{l}\text { No serious } \\
\text { risk of bias }\end{array}$ & $\begin{array}{l}\text { No serious } \\
\text { inconsistency }\end{array}$ & $\begin{array}{l}\text { No serious } \\
\text { indirectness }\end{array}$ & $\begin{array}{l}\text { Serious } \\
\text { imprecision }^{\text {b }}\end{array}$ & None & 37 & $\begin{array}{l}\text { Compared with decreased } \\
\text { sleep, increased sleep duration } \\
\text { resulted in lower weight after a } \\
\text { week (mean difference in } \\
\text { weight of } 0.24 \mathrm{~kg}, \mathrm{p}<0.001 \text {, } \\
\text { Cohen's } d=0.93 \text { ). There was a } \\
2.4 \mathrm{~h} \text { sleep duration difference } \\
\text { between conditions ( } 8.1 \mathrm{~h} \text { vs. } \\
10.5 \mathrm{~h} \text { for the decreased and } \\
\text { increased sleep, respectively). }\end{array}$ & MODERATE \\
\hline 12 & $\begin{array}{l}\text { Longitudinal } \\
\text { study }^{c}\end{array}$ & $\begin{array}{l}\text { Serious risk } \\
\text { of bias }^{d}\end{array}$ & $\begin{array}{l}\text { No serious } \\
\text { inconsistency }\end{array}$ & $\begin{array}{l}\text { No serious } \\
\text { indirectness }\end{array}$ & $\begin{array}{l}\text { No serious } \\
\text { imprecision }\end{array}$ & None & 40,726 & $\begin{array}{l}\text { Out of } 12 \text { longitudinal analyses, } \\
7 \text { reported a significant } \\
\text { association between short } \\
\text { sleep duration and adiposity } \\
\text { gain while } 5 \text { reported no } \\
\text { association. }\end{array}$ & VERY LOW \\
\hline 58 & $\begin{array}{l}\text { Cross- } \\
\text { sectional } \\
\text { study }^{\text {e }}\end{array}$ & $\begin{array}{l}\text { Serious risk } \\
\text { of bias }^{f}\end{array}$ & $\begin{array}{l}\text { No serious } \\
\text { inconsistency }\end{array}$ & $\begin{array}{l}\text { No serious } \\
\text { indirectness }\end{array}$ & $\begin{array}{l}\text { No serious } \\
\text { imprecision }\end{array}$ & $\begin{array}{l}\text { Large } \\
\text { effect and } \\
\text { evidence } \\
\text { of a dose- } \\
\text { response } \\
\text { gradient } \\
\text { (i.e. } \\
\text { longer } \\
\text { sleep } \\
\text { associated } \\
\text { with } \\
\text { lower } \\
\text { adiposity) }\end{array}$ & 470,303 & $\begin{array}{l}\text { Out of } 58 \text { cross-sectional } \\
\text { analyses, } 50 \text { reported a } \\
\text { significant association between } \\
\text { short sleep duration and } \\
\text { adiposity while } 8 \text { reported no } \\
\text { association. }\end{array}$ & LOW \\
\hline
\end{tabular}




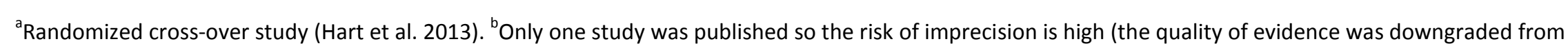
high to moderate). 'Includes 12 longitudinal studies (Magee et al. 2013b; Bartlett et al. 2012; Chang et al. 2013; Lytle et al. 2013; Mitchell et al. 2013; Hjorth et

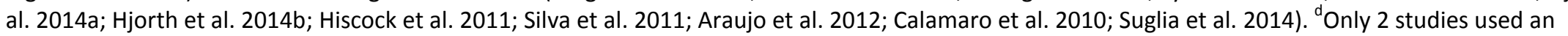
objective assessment of sleep duration (the quality of evidence was downgraded from low to very low). ${ }^{\mathrm{e}}$ Includes 58 cross-sectional studies (Hjorth et al. 2014a; Hjorth et al. 2014b; Hiscock et al. 2011; Silva et al. 2011; Araujo et al. 2012; Calamaro et al. 2010; Suglia et al. 2014; Butte et al. 2007; Chaput et al. 2014; Colley et al. 2012; Ekstedt et al. 2013; Katzmarzyk et al. 2015; Wong et al. 2013; Chaput et al. 2011; de Jong et al. 2012; Guo et al. 2012; Hense et al. 2011; Magee et al. 2013a; Padez et al. 2009; Park et al. 2012; Scharf et al. 2015; Sekine et al. 2002; Suglia et al. 2013; Von Kries et al. 2002; Wing et al. 2009; Bawazeer et al. 2009; Berentzen et al. 2014; Eisenmann et al. 2006; Ozturk et al. 2009; Peach et al. 2015; Shan et al. 2010; Stroebele et al. 2013; Awad et al. 2013; Martinez et al. 2014; Gupta et al. 2002; Al-Hazzaa et al. 2014; Al-Hazzaa et al. 2012; Bel et al. 2013; Culnan et al. 2013; Danielsen et al. 2010; Do et al. 2013; Garaulet et al. 2011; Huang et al. 2010; Knutson and Lauderdale 2007; Knutson 2005; Kuciene and Dulskiene 2014; Kong et al. 2011; Lee and Park 2014; Liou et al. 2010; Lowry et al. 2012; Martinez-Gomez et al. 2011; Meldrum and Restivo 2014; Morley et al. 2012; Pallesen et al. 2011; Park 2011; Sivertsen et al. 2014a; Stea et al. 2014; Vaezghasemi et al. 2012). ${ }^{\text {f } M o s t ~ s t u d i e s ~ u s e d ~ a ~ s u b j e c t i v e ~ a s s e s s m e n t ~ o f ~ s l e e p ~ w i t h ~ n o ~ p s y c h o m e t r i c ~ p r o p e r t i e s ~ r e p o r t e d ~(t h e ~ q u a l i t y ~ o f ~}$ evidence was downgraded from low to very low). However, the quality of evidence for the cross-sectional studies was upgraded to "low" because of the large effect observed and the evidence of a dose-response gradient between sleep duration and adiposity (i.e. longer sleep is associated with lower adiposity indicators). Note: Due to heterogeneity in the measurement of sleep and adiposity, a meta-analysis was not possible. 
Table 2. Association between sleep duration and emotional regulation in children and youth.

\begin{tabular}{|c|c|c|c|c|c|c|c|c|c|}
\hline \multirow{2}{*}{$\begin{array}{l}\text { No of } \\
\text { studies }\end{array}$} & \multirow[t]{2}{*}{ Design } & \multicolumn{5}{|c|}{ Quality Assessment } & \multirow{2}{*}{$\begin{array}{l}\text { No of } \\
\text { participants }\end{array}$} & \multirow{2}{*}{ Absolute effect } & \multirow{2}{*}{ Quality } \\
\hline & & Risk of bias & Inconsistency & Indirectness & Imprecision & Other & & & \\
\hline \multicolumn{10}{|c|}{$\begin{array}{l}\text { Mean age ranged between } 7.6 \text { and } 17.3 \text { years. Intervention studies were between } 2 \text { days and } 2 \text { weeks, and longitudinal studies were up to } 8 \text { years. Sleep duration } \\
\text { was assessed by actigraphy, polysomnography, parent report or self-report. Emotional regulation was assessed through various self-reported instruments. }\end{array}$} \\
\hline 4 & $\begin{array}{l}\text { Randomized } \\
\text { trial }^{\mathrm{a}}\end{array}$ & $\begin{array}{l}\text { No serious } \\
\text { risk of bias }\end{array}$ & $\begin{array}{l}\text { No serious } \\
\text { inconsistency }\end{array}$ & $\begin{array}{l}\text { No serious } \\
\text { indirectness }\end{array}$ & $\begin{array}{l}\text { No serious } \\
\text { imprecision }\end{array}$ & None & 277 & $\begin{array}{l}\text { After the treatment, } \\
\text { participants in the sleep } \\
\text { education group showed } \\
\text { significant improvements in } \\
\text { irritability and mood in the } \\
\text { morning compared to the } \\
\text { control group (Tamura and } \\
\text { Tanaka 2014). } \\
\text { Participants showed impaired } \\
\text { functioning in the short } \\
\text { (mean: } 8.1 \text { h) relative to the } \\
\text { long (mean: } 9.3 \text { h) sleep } \\
\text { condition on measures of } \\
\text { positive affective response } \\
\text { and emotion regulation } \\
\text { (Vriend et al. } 2013 \text { ). } \\
\text { Compared with healthy sleep } \\
\text { (control; } 10 \text { h in bed per night } \\
\text { for } 5 \text { nights), participants } \\
\text { rated themselves as } \\
\text { significantly more } \\
\text { tense/anxious, angry/hostile, } \\
\text { confused, fatigued, and less } \\
\text { vigorous during sleep } \\
\text { restriction ( } 6.5 \text { h in bed per } \\
\text { night for } 5 \text { nights). Parents } \\
\text { and adolescents also reported } \\
\text { greater } \\
\text { oppositionality/irritability and }\end{array}$ & $\mathrm{HIGH}$ \\
\hline
\end{tabular}




\begin{tabular}{|c|c|c|c|c|c|c|c|c|c|}
\hline & & & & & & & & $\begin{array}{l}\text { poorer emotional regulation } \\
\text { during sleep restriction } \\
\text { compared to control. There } \\
\text { were no differences in } \\
\text { depression or } \\
\text { hyperactivity/impulsivity } \\
\text { (Baum et al. 2014). } \\
\text { Participants reported more } \\
\text { positive affect (but no } \\
\text { difference in negative affect) } \\
\text { when rested ( } 8.5 \mathrm{~h} / \text { night for } 2 \\
\text { nights) relative to when sleep } \\
\text { deprived (6.5 } \mathrm{h} \text { the first night } \\
\text { then } 2 \mathrm{~h} \text { the } 2^{\text {nd }} \text { night) (Dagys } \\
\text { et al. } 2012 \text { ). }\end{array}$ & \\
\hline 11 & $\begin{array}{l}\text { Longitudinal } \\
\text { study }^{\mathrm{b}}\end{array}$ & $\begin{array}{l}\text { Serious risk } \\
\text { of bias }^{c}\end{array}$ & $\begin{array}{l}\text { No serious } \\
\text { inconsistency }\end{array}$ & $\begin{array}{l}\text { No serious } \\
\text { indirectness }\end{array}$ & $\begin{array}{l}\text { No serious } \\
\text { imprecision }\end{array}$ & None & 25,271 & $\begin{array}{l}\text { Out of } 11 \text { longitudinal } \\
\text { analyses, } 8 \text { reported that } \\
\text { longer sleep was related to } \\
\text { better emotional regulation at } \\
\text { follow-up while } 3 \text { reported no } \\
\text { association. }\end{array}$ & VERY LOW \\
\hline 47 & $\begin{array}{l}\text { Cross- } \\
\text { sectional }^{\text {study }}{ }^{d}\end{array}$ & $\begin{array}{l}\text { Serious risk } \\
\text { of bias }^{\mathrm{e}}\end{array}$ & $\begin{array}{l}\text { No serious } \\
\text { inconsistency }\end{array}$ & $\begin{array}{l}\text { No serious } \\
\text { indirectness }\end{array}$ & $\begin{array}{l}\text { No serious } \\
\text { imprecision }\end{array}$ & None & 480,925 & $\begin{array}{l}\text { Out of } 47 \text { cross-sectional } \\
\text { analyses, } 37 \text { reported that } \\
\text { longer sleep was related to } \\
\text { better emotional regulation, } 8 \\
\text { reported null findings, and } 2 \\
\text { reported opposite } \\
\text { associations. }\end{array}$ & VERY LOW \\
\hline
\end{tabular}

ancludes 3 randomized cross-over studies (Vriend et al. 2013; Baum et al. 2014; Dagys et al. 2012) and one randomized controlled trial (Tamura and Tanaka 2014). 'Includes 11 longitudinal studies (Asarnow et al. 2014; Barlett et al. 2012; Chang and Gable 2013; Frederiksen et al. 2004; Roberts and Duong 2014; Roberts et al. 2009; Kalak et al. 2014; Pasch et al. 2012; Lin and Yi 2015; Lumeng et al. 2007; Silva et al. 2011). 'Only one study used an objective assessment of sleep (the quality of evidence was downgraded from low to very low). 'Includes 47 cross-sectional studies (Lin and Yi 2015; Lumeng et al. 2007; Silva et al. 2011; Arman et al. 2011; Biggs et al. 2011; Bos et al. 2009; Nixon et al. 2008; levers-Landis et al. 2008; Lin et al. 2011; van der Heijden et al. 2013; Wang et al. 2013; Lehto and Uusitalo-Malmivaara 2014; Barnes 2015; Chen et al. 2006; de Souza and Hidalgo 2014; Dewald et al. 2012; Dewald-Kaufmann et al. 2013; Do et al. 2013; Fitzgerald et al. 2011; Gangwish et al. 2010; Gupta et al. 2002; Kang et al. 2014; Kubiszewski et al. 2014; Lam and Yang 2008; Lee et al. 2012; Lemola et al. 2015; Liu 2004; Liu and Zhou 2002; Lowry et al. 2012; McClure et al. 2014; McHale et al. 2011; Knight-Eily et al. 2011; Meijer et al. 2010; Paciencia et al. 


\section{Applied Physiology, Nutrition, and Metabolism}

2013; Pallesen et al. 2011; Perfect et al. 2014; Perkinson-Gloor et al. 2013; Park et al. 2013; Sarchiapone et al. 2014; Sivertsen et al. 2014b; Short et al. 2013a; Short et al. 2013b; Stea et al. 2014; Suzuki et al. 2011; Winsler et al. 2015; Wolfson and Carskadon 1998; Yen et al. 2010). ${ }^{\mathrm{e}}$ Most studies used a subjective assessment of sleep with no psychometric properties reported (the quality of evidence was downgraded from low to very low). Note: Due to heterogeneity in the measurement of sleep and emotional regulation, a meta-analysis was not possible. 
Table 3. Association between sleep duration and cognition in children and youth.

\begin{tabular}{|c|c|c|c|c|c|c|c|c|c|}
\hline \multirow{2}{*}{$\begin{array}{l}\text { No of } \\
\text { studies }\end{array}$} & \multirow[t]{2}{*}{ Design } & \multicolumn{5}{|c|}{ Quality Assessment } & \multirow{2}{*}{$\begin{array}{c}\text { No of } \\
\text { participants }\end{array}$} & \multirow{2}{*}{ Absolute effect } & \multirow{2}{*}{ Quality } \\
\hline & & Risk of bias & Inconsistency & Indirectness & Imprecision & Other & & & \\
\hline \multicolumn{10}{|c|}{$\begin{array}{l}\text { Mean age ranged between } 8 \text { and } 17 \text { years. Data were collected cross-sectionally and up to } 5 \text { years of follow-up. Sleep duration was assessed by actigraphy, } \\
\text { polysomnography, parent report or self-report. Cognition was measured by numerous computer testing modalities, and other tests/questionnaires: the CBCL, the } \\
\text { TEA test, the CCTT (versions 1-2), the WISC-III and the MFT. }\end{array}$} \\
\hline 1 & $\begin{array}{l}\text { Randomized } \\
\text { trial }^{a}\end{array}$ & $\begin{array}{l}\text { No serious } \\
\text { risk of bias }\end{array}$ & $\begin{array}{l}\text { No serious } \\
\text { inconsistency }\end{array}$ & $\begin{array}{l}\text { No serious } \\
\text { indirectness }\end{array}$ & $\begin{array}{l}\text { Serious } \\
\text { imprecision }^{\text {b }}\end{array}$ & None & 32 & $\begin{array}{l}\text { Short term memory, working } \\
\text { memory, divided attention } \\
\text { (CCTT-2) and math fluency } \\
\text { scores were lower in children in } \\
\text { the short sleep condition ( } 1 \mathrm{~h} \\
\text { later in bed for } 4 \text { nights) } \\
\text { compared to long sleep ( } 1 \mathrm{~h} \\
\text { earlier for } 4 \text { nights relative to } \\
\text { their typical bedtime). No } \\
\text { differences were found for } \\
\text { reaction time on alerting, } \\
\text { orienting, sustained (CCTT-1) or } \\
\text { executive attention tasks } \\
\text { between long and short sleep } \\
\text { conditions. Those who began in } \\
\text { the short sleep condition had } \\
\text { greater working memory and } \\
\text { sustained attention (CCTT-1) } \\
\text { than those who began in the } \\
\text { long sleep condition. }\end{array}$ & MODERATE \\
\hline 1 & $\begin{array}{l}\text { Longitudinal } \\
\text { study }^{c}\end{array}$ & $\begin{array}{l}\text { No serious } \\
\text { risk of bias }\end{array}$ & $\begin{array}{l}\text { No serious } \\
\text { inconsistency }\end{array}$ & $\begin{array}{l}\text { No serious } \\
\text { indirectness }\end{array}$ & $\begin{array}{l}\text { Serious } \\
\text { imprecision }^{d}\end{array}$ & None & 304 & $\begin{array}{l}\text { At 5-year follow-up, there were } \\
\text { no increased odds of having } \\
\text { learning problems across sleep } \\
\text { duration categories. }\end{array}$ & VERY LOW \\
\hline 4 & $\begin{array}{l}\text { Cross- } \\
\text { sectional } \\
\text { study }\end{array}$ & $\begin{array}{l}\text { Serious risk } \\
\text { of bias }^{f}\end{array}$ & $\begin{array}{l}\text { Serious } \\
\text { inconsistency } \\
\mathrm{g}\end{array}$ & $\begin{array}{l}\text { No serious } \\
\text { indirectness }\end{array}$ & $\begin{array}{l}\text { No serious } \\
\text { imprecision }\end{array}$ & None & 8,221 & $\begin{array}{l}\text { Kim et al. (2011) found no } \\
\text { association between sleep } \\
\text { duration and attention. } \\
\text { However, increased weekend } \\
\text { (but not weekday) sleep } \\
\text { duration was associated with } \\
\text { more omission errors on }\end{array}$ & VERY LOW \\
\hline
\end{tabular}




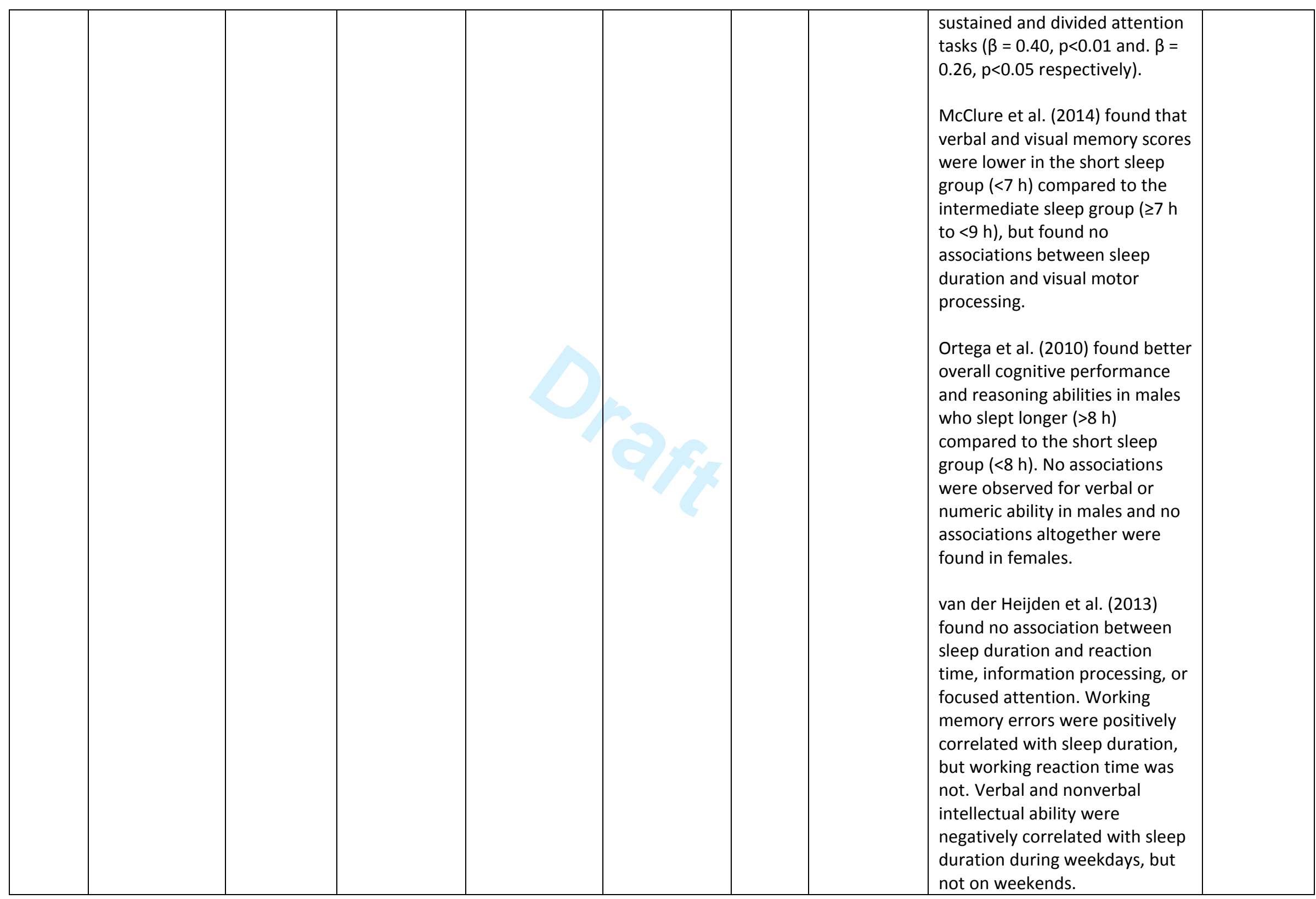


$\mathrm{CBCL}=$ Child Behaviour Checklist TEA = Test of Educational Ability; $\mathrm{CCTT}=$ Children's Colour Trails Test WISC III = Wechsler Intelligence Scale for Children-Third Edition; MFT = Math Fluency Task. ${ }^{a}$ Randomized cross-over study (Vriend et al. 2013). ${ }^{\mathrm{b}}$ Large standard deviations, small effect sizes and only one study was published so the risk of imprecision is high (the quality of evidence was downgraded from high to moderate). ${ }^{C}$ Includes 1 longitudinal study (Silva et al. 2011). ${ }^{d}$ Only one study was published so the risk of imprecision is high (the quality of evidence was downgraded from low to very low). ${ }^{\mathrm{e}}$ Includes 4 cross-sectional studies (Kim et al. 2011; McClure et al. 2014; Ortega et al. 2010; van der Heijden et al. 2013). ${ }^{f}$ All studies used a subjective assessment of sleep with no psychometric properties reported. ${ }^{g}$ Studies reported either positive, negative, or null findings. Therefore, the quality of evidence was downgraded from low to very low. Note: Due to heterogeneity in the measurement of sleep and cognition, a meta-analysis was not possible. 
Table 4. Association between sleep duration and academic achievement in children and youth.

\begin{tabular}{|c|c|c|c|c|c|c|c|c|c|}
\hline \multirow{2}{*}{$\begin{array}{l}\text { No of } \\
\text { studies }\end{array}$} & \multirow[t]{2}{*}{ Design } & \multicolumn{5}{|c|}{ Quality Assessment } & \multirow{2}{*}{$\begin{array}{c}\text { No of } \\
\text { participants }\end{array}$} & \multirow{2}{*}{ Absolute effect } & \multirow{2}{*}{ Quality } \\
\hline & & Risk of bias & Inconsistency & Indirectness & Imprecision & Other & & & \\
\hline \multicolumn{10}{|c|}{$\begin{array}{l}\text { Mean age ranged between } 12 \text { and } 17.3 \text { years. Data were collected cross-sectionally and up to } 6 \text { years of follow-up. Sleep duration was assessed by parent report or } \\
\text { self-report. Academic achievement metrics were assessed by official school transcripts, GPA, self-report questionnaire, WJ-R, and NAPLAN. }\end{array}$} \\
\hline 4 & $\begin{array}{l}\text { Longitudinal } \\
\text { study }^{a}\end{array}$ & $\begin{array}{l}\text { Serious risk } \\
\text { of bias }^{b}\end{array}$ & $\begin{array}{l}\text { No serious } \\
\text { inconsistency }\end{array}$ & $\begin{array}{l}\text { No serious } \\
\text { indirectness }\end{array}$ & $\begin{array}{l}\text { No serious } \\
\text { imprecision }\end{array}$ & None & 10,286 & $\begin{array}{l}3 \text { out of } 4 \text { studies reported } \\
\text { poorer grades with short sleep } \\
\text { duration (Fredriksen et al. 2004; } \\
\text { Roberts et al. 2009; Lin et al. } \\
\text { 2015). Asarnow et al. (2014) } \\
\text { reported that short sleep } \\
\text { duration did not predict } \\
\text { cumulative GPA at follow-up. }\end{array}$ & VERY LOW \\
\hline 17 & $\begin{array}{l}\text { Cross- } \\
\text { sectional } \\
\text { study }^{c}\end{array}$ & $\begin{array}{l}\text { Serious risk } \\
\text { of bias }^{d}\end{array}$ & $\begin{array}{l}\text { No serious } \\
\text { inconsistency }\end{array}$ & $\begin{array}{l}\text { Serious } \\
\text { indirectness }^{\mathrm{e}}\end{array}$ & $\begin{array}{l}\text { No serious } \\
\text { imprecision }\end{array}$ & None & 30,249 & $\begin{array}{l}11 \text { of } 17 \text { total studies showed } \\
\text { associations for longer sleep } \\
\text { duration and better academic } \\
\text { achievement, or shorter sleep } \\
\text { duration and poor academic } \\
\text { achievement measured by self- } \\
\text { report, official school grades, or } \\
\text { standardized tests (Lin et al. } \\
\text { 2015; Eide and Showalter 2012; } \\
\text { Stroebele et al. 2013; Kang et al. } \\
\text { 2014; Pallesen et al. 2011; } \\
\text { Perkinson-Gloor et al. 2013; } \\
\text { Quevedo-Blasco and Quevedo- } \\
\text { Blasco 2011; Stea et al. 2014; } \\
\text { Titova et al. 2015; van der Vinne } \\
\text { et al. 2015; Wolfson and } \\
\text { Carskadon 1998). } \\
5 \text { studies found no association } \\
\text { between sleep duration and } \\
\text { academic achievement (Arbabi } \\
\text { et al. 2015; O'Dea and Mugridge } \\
2012 ; \text { Boschloo et al. 2013; } \\
\text { McHale et al. 2011; Short et al. }\end{array}$ & VERY LOW \\
\hline
\end{tabular}




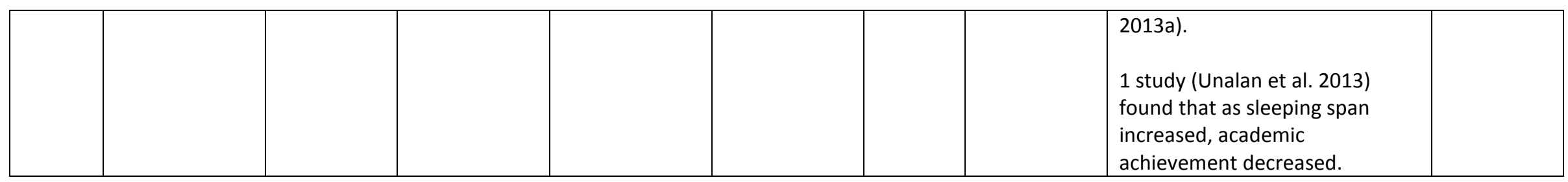

GPA = Grade Point Average; WJ-R = Woodcock-Johnson Psycho-Educational Battery-Revised test; NAPLAN = National Assessment Program for Literacy and Numeracy. ${ }^{a}$ Includes 4 longitudinal studies (Asarmow et al. 2014; Fredriksen et al. 2004; Roberts et al. 2009; Lin et al. 2005). ${ }^{b}$ All studies used a subjective assessment of sleep with no psychometric properties reported (the quality of evidence was downgraded from low to very low). ${ }^{C}$ Includes $17 \mathrm{cross}$-sectional studies (Lin et al. 2015; Arbabi et al. 2015; Eide and Showalter 2012; O'Dea and Mugridge 2012; Stroebele et al. 2013; Boschloo et al. 2013; Kang et al. 2014; McHale et al. 2011; Pallesen et al. 2011; Perkinson-Gloor et al. 2013; Quevedo-Blasco and Quevedo-Blasco 2011; Short et al. 2013a; Stea et al. 2014; Titova et al. 2015; Unalan et al. 2013; van der Vinne et al. 2015; Wolfson and Carskadon 1998). ${ }^{\mathrm{d}}$ Most studies used a subjective assessment of sleep with no psychometric properties reported. ${ }^{e}$ Of the 17 studies, 8 examined student's actual grades/test results while 9 studies used self-report metrics (not all asked for students to report their grades; some questions referred to if students felt they feel behind in school, how well to perform relative to your peers academically, etc.). It may be reasonable to assume that the 'gold standard' would be to assess children/youth's actual grades. Since only half of the studies did this, downgrading has been decided (from low to very low). Note: Due to heterogeneity in the measurement of sleep and academic achievement, a meta-analysis was not possible. 
Table 5. Association between sleep duration and quality of life/well-being in children and youth.

\begin{tabular}{|c|c|c|c|c|c|c|c|c|c|}
\hline \multirow{2}{*}{$\begin{array}{l}\text { No of } \\
\text { studies }\end{array}$} & \multirow[t]{2}{*}{ Design } & \multicolumn{5}{|c|}{ Quality Assessment } & \multirow{2}{*}{$\begin{array}{c}\text { No of } \\
\text { participants }\end{array}$} & \multirow{2}{*}{ Absolute effect } & \multirow{2}{*}{ Quality } \\
\hline & & Risk of bias & Inconsistency & Indirectness & Imprecision & Other & & & \\
\hline \multicolumn{10}{|c|}{$\begin{array}{l}\text { Mean age ranged between } 11 \text { and } 18 \text { years. Data were collected cross-sectionally and up to } 1 \text { year. Sleep duration was assessed by self-report. Quality of } \\
\text { life/well-being was assessed by self-report as life satisfaction (Mental Health Diagnostic Interview Schedule for Children, Version IV), positive attitude towards life } \\
\text { (Berne Questionnaire on Adolescent Subjective Well-Being), and self-rated health (single question). }\end{array}$} \\
\hline 1 & $\begin{array}{l}\text { Longitudinal } \\
\text { study }^{a}\end{array}$ & $\begin{array}{l}\text { Serious risk } \\
\text { of bias }^{b}\end{array}$ & $\begin{array}{l}\text { No serious } \\
\text { inconsistency }\end{array}$ & $\begin{array}{l}\text { No serious } \\
\text { indirectness }\end{array}$ & $\begin{array}{l}\text { Serious } \\
\text { imprecision }^{c}\end{array}$ & None & 2,855 & $\begin{array}{l}\text { Participants with short sleep } \\
\text { duration }(\leq 6 \mathrm{~h}) \text { at baseline had } \\
\text { increased odds of low life } \\
\text { satisfaction }(\mathrm{OR}=1.73,95 \% \mathrm{Cl} \text { : } \\
1.17-1.54 ; p<0.05) \text {. }\end{array}$ & VERY LOW \\
\hline 2 & $\begin{array}{l}\text { Cross- } \\
\text { sectional } \\
\text { study }^{d}\end{array}$ & $\begin{array}{l}\text { Serious risk } \\
\text { of bias }^{\mathrm{e}}\end{array}$ & $\begin{array}{l}\text { No serious } \\
\text { inconsistency }\end{array}$ & $\begin{array}{l}\text { No serious } \\
\text { indirectness }\end{array}$ & $\begin{array}{l}\text { No serious } \\
\text { imprecision }\end{array}$ & None & 139,305 & $\begin{array}{l}\text { Both studies reported better } \\
\text { quality of life/well-being with } \\
\text { longer sleep duration. }\end{array}$ & VERY LOW \\
\hline
\end{tabular}

${ }^{a}$ Includes 1 longitudinal study (Roberts et al. 2009). ' Sleep duration was self-reported with no psychometric properties reported. 'Only one study was published so the risk of imprecision is high. Therefore, the quality of evidence was downgraded from low to very low ${ }^{\mathrm{d}}$ Includes 2 cross-sectional studies (Perkinson-Gloor et al. 2013; Do et al. 2013). ${ }^{\mathrm{e}}$ Both studies used a subjective assessment of sleep with no psychometric properties reported (the quality of evidence was

downgraded from low to very low). Note: Due to heterogeneity in the measurement of sleep and quality of life/well-being, a meta-analysis was not possible. 
Table 6. Association between sleep duration and harms/injuries in children and youth.

\begin{tabular}{|c|c|c|c|c|c|c|c|c|c|}
\hline \multirow{2}{*}{$\begin{array}{l}\text { No of } \\
\text { studies }\end{array}$} & \multirow[t]{2}{*}{ Design } & \multicolumn{5}{|c|}{ Quality Assessment } & \multirow{2}{*}{$\begin{array}{l}\text { No of } \\
\text { participants }\end{array}$} & \multirow{2}{*}{ Absolute effect } & \multirow{2}{*}{ Quality } \\
\hline & & Risk of bias & Inconsistency & Indirectness & Imprecision & Other & & & \\
\hline \multicolumn{10}{|c|}{$\begin{array}{l}\text { Mean age ranged between 8-14 years. Data were collected cross-sectionally and up to } 4 \text { years. Sleep duration was assessed by actigraphy, parent report or self- } \\
\text { report. Harms/injuries were assessed by structured health interviews with parents, children and school nurses. }\end{array}$} \\
\hline 1 & $\begin{array}{l}\text { Longitudinal } \\
\text { study }^{a}\end{array}$ & $\begin{array}{l}\text { No serious } \\
\text { risk of bias }\end{array}$ & $\begin{array}{l}\text { No serious } \\
\text { inconsistency }\end{array}$ & $\begin{array}{l}\text { No serious } \\
\text { indirectness }\end{array}$ & $\begin{array}{l}\text { Serious } \\
\text { imprecision }^{\mathrm{b}}\end{array}$ & None & 617 & $\begin{array}{l}\text { Children who slept }<10 \mathrm{~h} \text { at age } \\
7 \text { had greater odds of migraine } \\
(\mathrm{OR}=1.83, \mathrm{p}<0.05) \text {, but not } \\
\text { tension-type headache, at age } \\
11 .\end{array}$ & VERY LOW \\
\hline 1 & $\begin{array}{l}\text { Cross- } \\
\text { sectional } \\
\text { study }^{c}\end{array}$ & $\begin{array}{l}\text { Serious risk } \\
\text { of bias }^{d}\end{array}$ & $\begin{array}{l}\text { No serious } \\
\text { inconsistency }\end{array}$ & $\begin{array}{l}\text { No serious } \\
\text { indirectness }\end{array}$ & $\begin{array}{l}\text { Serious } \\
\text { imprecision }^{\text {e }}\end{array}$ & None & 1,429 & $\begin{array}{l}\text { Adolescents who slept }<7 \\
\text { h/weeknight did not have } \\
\text { greater odds of single-injury vs. } \\
\text { adolescents who slept } \geq 7 \\
\text { h/weeknight. However, } \\
\text { adolescents who slept }<7 \\
\text { h/weeknight were more likely } \\
\text { to have experienced multiple } \\
\text { episodes of injury during the } 3 \\
\text { months prior to the survey vs. } \\
\text { those who slept } \geq 7 \\
\text { h/weeknight (OR }=2.2,95 \% \mathrm{Cl} \text { : } \\
\text { 1.1-4.8; } \mathrm{p}<0.05) .\end{array}$ & VERY LOW \\
\hline 2 & $\begin{array}{l}\text { Case-control } \\
\text { study }^{f}\end{array}$ & $\begin{array}{l}\text { Serious risk } \\
\text { of bias }^{\mathrm{g}}\end{array}$ & $\begin{array}{l}\text { No serious } \\
\text { inconsistency }\end{array}$ & $\begin{array}{l}\text { No serious } \\
\text { indirectness }\end{array}$ & $\begin{array}{l}\text { No serious } \\
\text { imprecision }\end{array}$ & None & 789 & $\begin{array}{l}\text { Raffi et al. ( } 2013 \text { ) found that } \\
\text { sleep duration was shorter in } \\
\text { the injury group vs. the non- } \\
\text { injury group ( } 8.98 \pm 1.36 \text { vs. } \\
9.91 \pm 1.06 \mathrm{~h} / \mathrm{night} \text {, } \\
\text { respectively, } \mathrm{p}<0.001 \text { ). In } \\
\text { contrast, Li et al. (2008) found } \\
\text { no differences in sleep } \\
\text { duration in the case vs. control } \\
\text { groups. }\end{array}$ & VERY LOW \\
\hline
\end{tabular}

${ }^{a}$ Includes 1 longitudinal study (Waldie et al. 2014). ${ }^{b}$ Only one study was published so the risk of imprecision is high. Therefore, the quality of evidence was

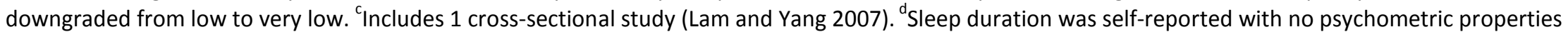




\section{Applied Physiology, Nutrition, and Metabolism}

reported. ${ }^{e}$ Only one study was published so the risk of imprecision is high. Therefore, the quality of evidence was downgraded from low to very low. Includes 2 case-control studies (Li et al. 2008; Rafii et al. 2013). ${ }^{\text {S}}$ Sleep duration was self-reported in both studies with no psychometric properties reported. Therefore, the quality of evidence was downgraded from low to very low. Note: Due to heterogeneity in the measurement of sleep and harms/injuries, a meta-analysis was not possible. 
Table 7. Association between sleep duration and cardiometabolic biomarkers in children and youth.

\begin{tabular}{|c|c|c|c|c|c|c|c|c|c|}
\hline \multirow{2}{*}{$\begin{array}{l}\text { No of } \\
\text { studies }\end{array}$} & \multirow[t]{2}{*}{ Design } & \multicolumn{5}{|c|}{ Quality Assessment } & \multirow{2}{*}{$\begin{array}{c}\text { No of } \\
\text { participants }\end{array}$} & \multirow{2}{*}{ Absolute effect } & \multirow{2}{*}{ Quality } \\
\hline & & Risk of bias & Inconsistency & Indirectness & Imprecision & Other & & & \\
\hline \multicolumn{10}{|c|}{$\begin{array}{l}\text { Mean age ranged between } 7.9 \text { and } 16.7 \text { years. Data were collected cross-sectionally and up to } 5 \text { years. Sleep duration was assessed by actigraphy, } \\
\text { polysomnography, parent report or self-report. Cardiometabolic biomarkers were measured objectively using fasting and non-fasting blood samples, blood pressure } \\
\text { devices, various assays, Holter monitors, elastic electrode belts, conventional lab methods, all performed by trained research staff or nurses. }\end{array}$} \\
\hline 3 & $\begin{array}{l}\text { Longitudinal } \\
\text { study }^{a}\end{array}$ & $\begin{array}{l}\text { No serious } \\
\text { risk of bias }\end{array}$ & $\begin{array}{l}\text { No serious } \\
\text { inconsistency }\end{array}$ & $\begin{array}{l}\text { No serious } \\
\text { indirectness }\end{array}$ & $\begin{array}{l}\text { No serious } \\
\text { imprecision }\end{array}$ & None & 1,900 & $\begin{array}{l}\text { Hjorth et al. (2014a) showed } \\
\text { that changes in sleep duration } \\
\text { were negatively associated } \\
\text { with changes in HOMA-IR ( } \beta= \\
-0.18,95 \% \mathrm{Cl} \text { : }-0.36 \text { to } 0.01 ; \\
\text { p<0.05) over a } 200 \text { day follow- } \\
\text { up period. Short sleep } \\
\text { duration was also associated } \\
\text { with an increased Metabolic } \\
\text { Syndrome score after the } \\
\text { follow-up period ( } r=-0.10, \beta= \\
-0.46,95 \% \text { Cl: }-0.87 \text { to }-0.04 ; \\
\text { p=0.03). However, changes in } \\
\text { sleep duration were not } \\
\text { associated with mean arterial } \\
\text { pressure, fasting plasma } \\
\text { triglycerides or HDL } \\
\text { cholesterol, over the follow- } \\
\text { up period. } \\
\text { Hancox and Landhuis ( } 2012 \text { ) } \\
\text { showed that sleep duration } \\
\text { was not associated with } \\
\text { HbA1c or with greater odds of } \\
\text { pre-diabetes at age } 32 \text { years. } \\
\text { Archbold et al. ( } 2012 \text { ) } \\
\text { reported that a decrease in } \\
\text { sleep duration was associated } \\
\text { with an increase in SBP ( } \beta=-\end{array}$ & LOW \\
\hline
\end{tabular}




\begin{tabular}{|c|c|c|c|c|c|c|c|c|c|}
\hline & & & & & & & & $\begin{array}{l}0.008, \mathrm{SE}=0.004, \mathrm{p}=0.042) \\
\text { over a } 5 \text {-year follow-up } \\
\text { period. However, the change } \\
\text { in sleep duration was not } \\
\text { associated with } \mathrm{DBP}(\beta=- \\
0.006, \mathrm{SE}=0.004, \mathrm{p}=0.144) .\end{array}$ & \\
\hline 16 & $\begin{array}{l}\text { Observational } \\
\text { study }^{b}\end{array}$ & $\begin{array}{l}\text { Serious risk } \\
\text { of bias }^{c}\end{array}$ & $\begin{array}{l}\text { Serious } \\
\text { inconsistency }^{d}\end{array}$ & $\begin{array}{l}\text { No serious } \\
\text { indirectness }\end{array}$ & $\begin{array}{l}\text { No serious } \\
\text { imprecision }\end{array}$ & None & 27,530 & $\begin{array}{l}\text { Blood pressure ( } 7 \text { studies): } \\
1 \text { study (Kuciene and } \\
\text { Dulskiene 2014) showed short } \\
\text { sleep (<7 h) was associated } \\
\text { with higher SBP, DBP and } \\
\text { likelihood of being } \\
\text { hypertensive. } \\
1 \text { study (Paciencia et al. 2013) } \\
\text { showed longer sleep duration } \\
\text { ( } \geq 9.5 \text { h) was associated with } \\
\text { higher SBP. } \\
2 \text { studies (Peach et al. 2015; } \\
\text { Rey-Lopez et al. 2014) showed } \\
\text { no association between sleep } \\
\text { duration and SBP or } \\
\text { hypertension risk. } \\
3 \text { studies (Wells 2008; Lee and } \\
\text { Park 2014; Meininger et al. } \\
2014 \text { ) showed mixed findings } \\
\text { (null and expected) for short } \\
\text { and/or long sleep duration } \\
\text { and SBP/DBP. } \\
\text { CV risk and function (5 } \\
\text { studies): } \\
4 \text { studies (Michels et al. 2013; } \\
\text { Berentzen et al. 2014; Narang } \\
\text { et al. 2012; Rey-Lopez et al. } \\
2014 \text { ) found no association }\end{array}$ & VERY LOW \\
\hline
\end{tabular}




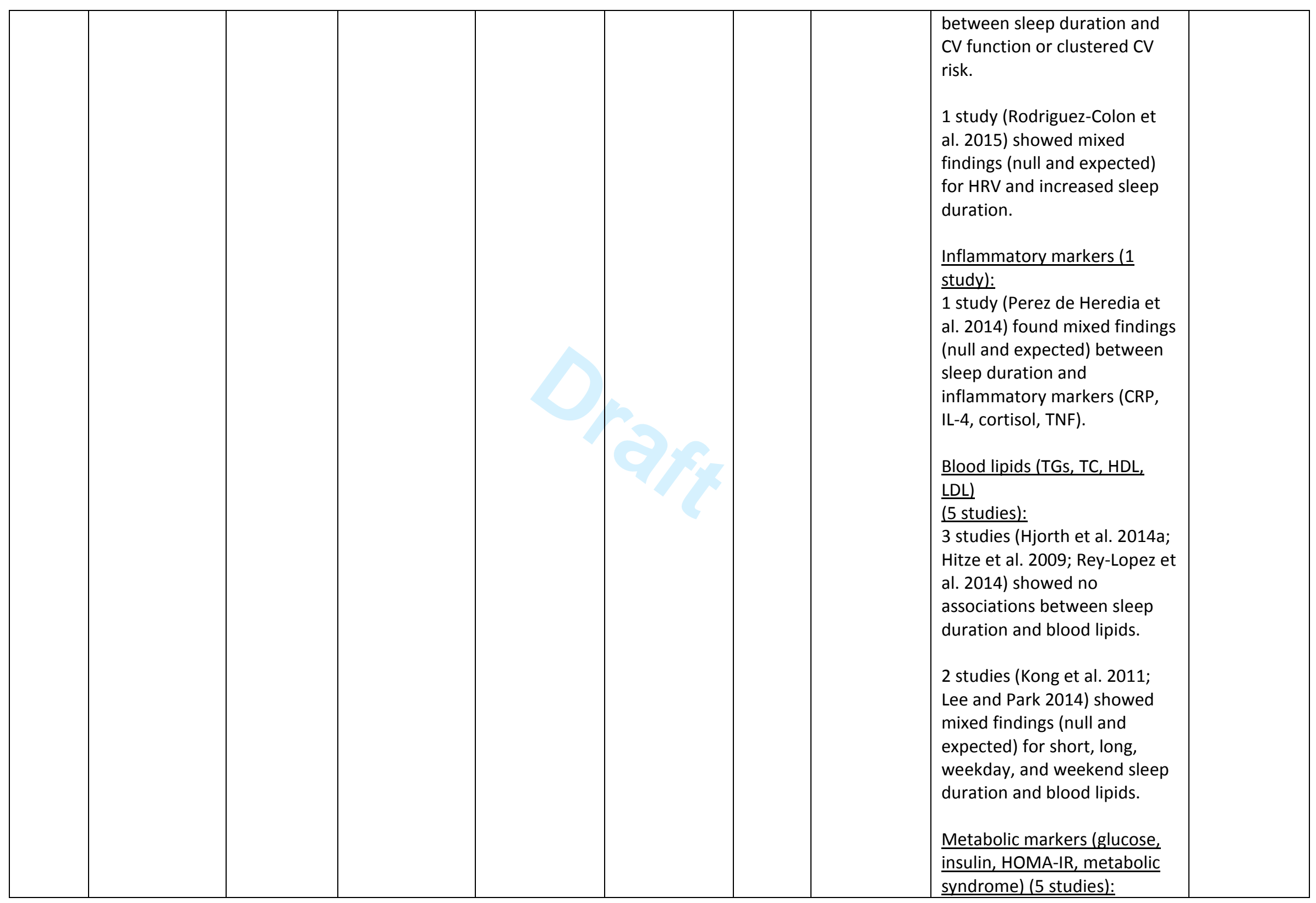




\begin{tabular}{|l|l|l|l|l|l|l|}
\hline & & & & & $\begin{array}{l}\text { 2 studies (Lee and Park 2014; } \\
\text { Rey-Lopez et al. 2014) showed } \\
\text { no association between sleep } \\
\text { duration and metabolic } \\
\text { markers. }\end{array}$ \\
& & & & & & $\begin{array}{l}\text { ladies (Hjorth et al. 2014a; } \\
\text { Javaheri et al. 2011; Hitze et } \\
\text { al. 2009) showed mixed } \\
\text { findings (null and expected) } \\
\text { for short and long sleep } \\
\text { duration and metabolic } \\
\text { markers. }\end{array}$ \\
\hline
\end{tabular}

$\mathrm{SBP}=$ systolic blood pressure; $\mathrm{DBP}=$ diastolic blood pressure; $\mathrm{TGs}=$ triglycerides; $\mathrm{TC}=$ total cholesterol; $\mathrm{LDL}=$ low density lipoprotein; $\mathrm{HDL}=$ high density lipoprotein; CV = cardiovascular; HRV = heart rate variability; CRP = C-reactive protein; IL-4 = interleukin-4; TNF = tumor necrosis factor; HOMA-IR = homeostasis model assessment of insulin resistance. ${ }^{\text {IIncludes } 3}$ longitudinal studies (Hjorth et al. 2014a; Hancox and Landhuis 2012; Archbold et al. 2012). bIncludes 16 cross-sectional studies (Hjorth et al. 2014a; Peach et al. 2015; Michels et al. 2013; Berentzen et al. 2014; Wells 2008; Javaheri et al. 2011; Rodriguez-Colon et al. 2015; Perez de Heredia et al. 2014; Hitze et al. 2009; Kong et al. 2011; Kuciene and Dulskiene 2014; Lee and Park 2014; Meininger et al. 2014; Narang et al. 2012; Paciencia et al. 2013; Rey-Lopez et al. 2014). 'Most studies used a subjective assessment of sleep with no psychometric properties reported. ${ }^{d}$ Mixed findings observed. Therefore, the quality of evidence was downgraded from low to very low. Note: Due to heterogeneity in the measurement of sleep and cardiometabolic biomarkers, a meta-analysis was not possible. 
Table 8. High-level summary of findings by health indicator.

\begin{tabular}{|c|c|c|c|}
\hline Health Indicator & \# of studies & Quality of Evidence & Summary of Findings \\
\hline \multicolumn{4}{|l|}{ Critical } \\
\hline Adiposity & 71 & $\begin{array}{l}\text { Very low to } \\
\text { moderate }\end{array}$ & $\begin{array}{l}\mathrm{N}=58 \text { studies reported a significant association } \\
\text { between short sleep duration and adiposity. } \\
\mathrm{N}=13 \text { studies reported null findings. }\end{array}$ \\
\hline Emotional Regulation & 62 & Very low to high & $\begin{array}{l}\mathrm{N}=49 \text { studies reported that longer sleep duration was } \\
\text { associated with better emotional regulation. } \\
\mathrm{N}=11 \text { studies reported null findings. } \\
\mathrm{N}=2 \text { studies reported opposite associations. }\end{array}$ \\
\hline Cognition & 6 & $\begin{array}{l}\text { Very low to } \\
\text { moderate }\end{array}$ & $\begin{array}{l}\mathrm{N}=5 \text { studies reported mixed findings. } \\
\mathrm{N}=1 \text { study reported null findings. }\end{array}$ \\
\hline Academic Achievement & 21 & Very low & $\begin{array}{l}\mathrm{N}=14 \text { studies reported that longer sleep duration was } \\
\text { associated with better academic achievement. } \\
\mathrm{N}=6 \text { studies reported null findings. } \\
\mathrm{N}=1 \text { study reported opposite associations. }\end{array}$ \\
\hline Quality of Life/Well-Being & 3 & Very low & $\begin{array}{l}\mathrm{N}=3 \text { studies reported better quality of life/well-being } \\
\text { with longer sleep duration. }\end{array}$ \\
\hline Harms/Injuries & 4 & Very low & $\begin{array}{l}\mathrm{N}=2 \text { studies reported mixed findings. } \\
\mathrm{N}=1 \text { study reported that short sleep duration was } \\
\text { associated with more injuries. } \\
\mathrm{N}=1 \text { study reported null findings. }\end{array}$ \\
\hline \multicolumn{4}{|l|}{ Important } \\
\hline Cardiometabolic biomarkers & 19 & Very low to low & $\begin{array}{l}\mathrm{N}=11 \text { studies reported mixed findings. } \\
\mathrm{N}=6 \text { studies reported null findings. } \\
\mathrm{N}=1 \text { study reported that longer sleep duration was } \\
\text { associated with adverse cardiometabolic health. } \\
\mathrm{N}=1 \text { study reported opposite associations. }\end{array}$ \\
\hline
\end{tabular}




\section{Figure Legends}

Figure 1. PRISMA flow diagram for the identification, screening, eligibility, and inclusion of studies. 

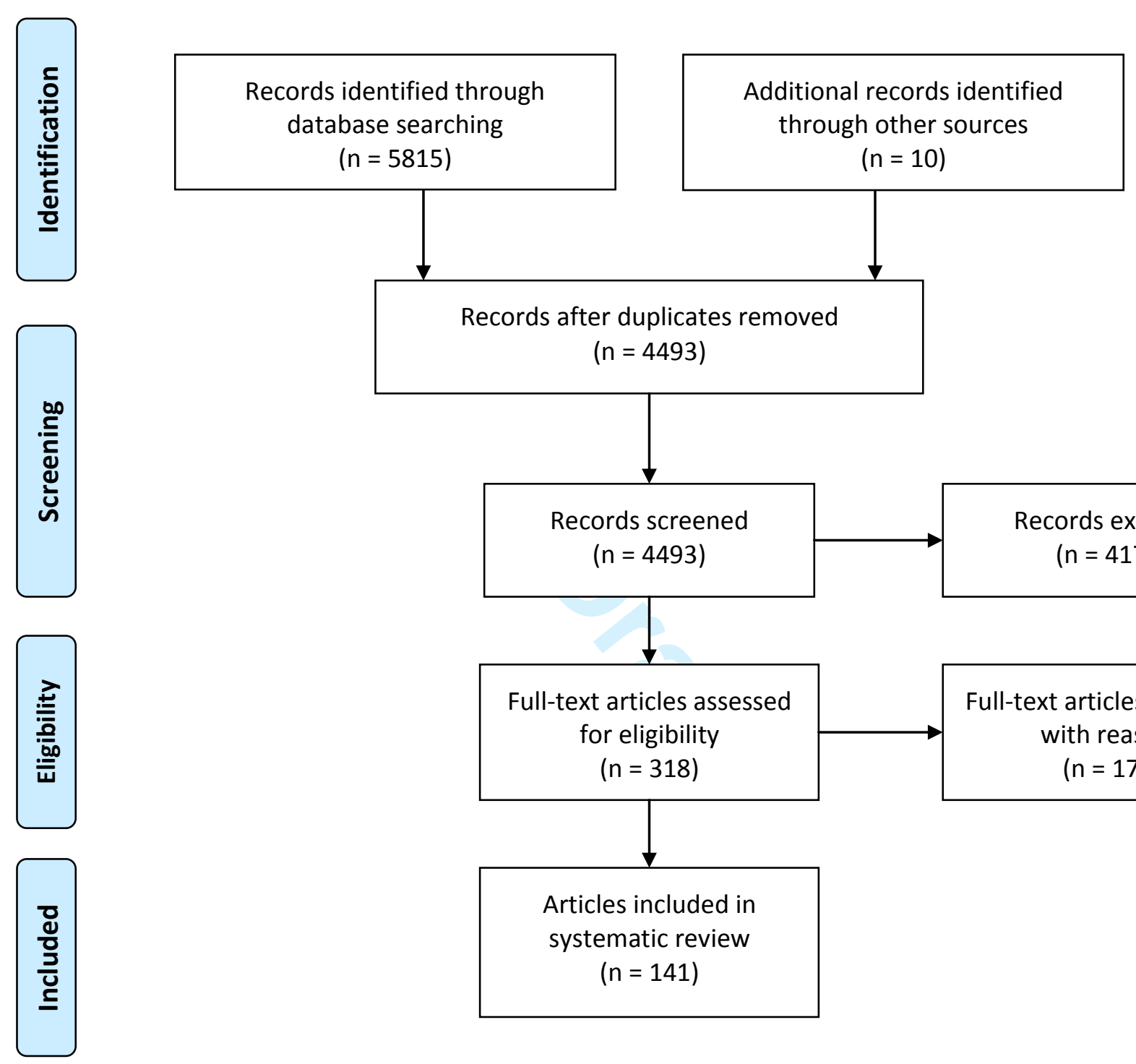

Records excluded $(n=4175)$

Full-text articles excluded, with reasons $(n=177)$ 